Earth Surf. Dynam. Discuss., https://doi.org/10.5194/esurf-2017-49

Manuscript under review for journal Earth Surf. Dynam.

Discussion started: 1 August 2017

(c) Author(s) 2017. CC BY 4.0 License.

\title{
Terrestrial laser scanning for quantifying small-scale vertical movements of the ground surface in Artic permafrost regions
}

\author{
Sabrina Marx ${ }^{1}$, Katharina Anders ${ }^{1}$, Sofia Antonova ${ }^{2}$, Inga Beck ${ }^{1}$, Julia Boike ${ }^{2}$, Philip Marsh ${ }^{3}$, Moritz \\ Langer $^{2,4}$, Bernhard Höfle ${ }^{1,5}$ \\ $5 \quad{ }^{1}$ GIScience, Institute of Geography, Heidelberg University, Heidelberg, 69120 Germany \\ ${ }^{2}$ Alfred Wegener Institute, Helmholtz Center for Polar and Marine Research, Potsdam, 14473, Germany \\ ${ }^{3}$ Cold Regions Research Centre, Wilfrid Laurier University, Waterloo, N2L 3C5, ON, Canada \\ ${ }^{4}$ Department of Geography, Humboldt-University, Berlin, 10099, Germany \\ ${ }^{5}$ Heidelberg Center for the Environment (HCE), Heidelberg University, Heidelberg, 69120, Germany
}

Correspondence to: Sabrina Marx (marx@ uni-heidelberg.de)

\begin{abstract}
Three-dimensional data acquired by terrestrial laser scanning (TLS) provides an accurate representation of Earth's surface, which is commonly used to detect and quantify topographic changes on a small scale. However, in Arctic permafrost regions the tundra vegetation and the micro-topography have significant effects on the surface representation in the captured dataset. The resulting spatial sampling of the ground is never identical between two TLS surveys. Thus, monitoring of heave and subsidence in the context of permafrost processes are challenging. This study evaluates TLS for quantifying small-scale vertical movements in an area located within the continuous permafrost zone, $50 \mathrm{~km}$ north-east of Inuvik, Northwest Territories, Canada. We propose a novel filter strategy, which accounts for spatial sampling effects and identifies TLS points suitable for multi-temporal deformation analyses. Further important prerequisites must be met, such as accurate co-registration of the TLS datasets. We found that if the ground surface is captured by more than one TLS scan position, plausible subsidence rates (up to mm-scale) can be derived; compared to e.g. standard raster-based DEM difference maps which contain change rates strongly affected by sampling effects.
\end{abstract}

\section{Introduction}

Approximately one quarter of Northern hemisphere lands contain permafrost, which is defined as ground material that remains at or below $0{ }^{\circ} \mathrm{C}$ during at least two consecutive years. Its depth varies from centimetres to hundreds of metres and reaches up to $1500 \mathrm{~m}$ below the land surface in particular areas of Eastern Siberia (Melnikov, 1967). Large quantities of organic carbon are preserved in the permafrost, an amount that is likely twice as large as the current quantity of carbon in the atmosphere (Zimov et al., 2006). Current global climate warming is more intense in high latitudes (IPCC, 2013) and causes permafrost to warm and thaw, and, consequently, to release the carbon into atmosphere, amplifying global warming. Lowering of land surface due to permafrost thaw can manifest in various ways, including thermokarst, thaw slumps, and slope failures (Rowland

30 et al., 2010). Besides these spatially confined processes, relatively uniform and gradual isotropic thaw subsidence, which is not exhibited by any surface disturbance, was recently observed in Arctic permafrost regions (e.g. Shiklomanov et al., 2013). 
Earth Surf. Dynam. Discuss., https://doi.org/10.5194/esurf-2017-49

Manuscript under review for journal Earth Surf. Dynam.

Discussion started: 1 August 2017

(c) Author(s) 2017. CC BY 4.0 License.

In-situ measurements on such isotropic subsidence are often performed using differential global positioning system (DGPS) measurements (e.g. Little et al., 2003; Shiklomanov et al., 2013; Beck et al., 2015; Streletskiy et al., 2016) or thaw-tubes (e.g. Nixon et al., 2003; Short et al., 2014). However, such discrete point measurements do not allow a detailed assessment of surface deformations. As a result, remote sensing techniques have been increasingly exploited to provide data in a more comprehensive spatial coverage as well as higher spatial and temporal resolution (Arenson et al., 2016). For example, Günther et al. (2015) used multi-temporal Digital Elevation Models (DEM), obtained from aerial and satellite imagery, and found an average net subsidence of $3.6 \pm 1.8 \mathrm{~m}$ over 62 years in an ice-rich permafrost area of Siberian Arctic. Differential Synthetic Aperture Radar interferometry (DInSAR) is another remote-sensing technique which recently has been adapted for monitoring permafrost thaw subsidence (e.g. Liu et al., 2010; Short et al., 2011). However, the usage of DInSAR can be limited due to

10 interferometric phase decorrelation (e.g. Beck et al., 2015; Antonova et al., 2016) as well as atmospheric effects (e.g. Short et al., 2011). Bhardwaj et al. (2016) identifies Light detection and ranging (LiDAR), also referred to as laser scanning (Höfle and Rutzinger, 2011), as potentially being the best tool for increasing the performance of measuring permafrost-related processes, such as mass movements, vegetation dynamics and topographical characteristics (Bhardwaj et al., 2016). By combining point measurements with airborne laser scanning (ALS), and geophysical datasets, the study of Hubbard et al. (2013) indicates a

15 close linkage between micro-topography, active layer, and permafrost variability. This linkage of subsurface and land surface variabilities emphasizes the potential of laser scanning to indirectly characterize subsurface properties in permafrost environments in a non-invasive manner (Hubbard et al., 2013).

In an extensive review, Bhardwaj et al. (2016) discuss the application of laser scanning for monitoring permafrost processes. Terrestrial laser scanning (TLS) was first used in high-mountain environments for the study of rock glaciers (Avian et al.,

20 2009, 2008; Bodin et al., 2008; Deline et al., 2008). As the accuracy of laser scanning systems has improved, ALS and TLS have been used to study lowland sub-Arctic permafrost regions (Chasmer et al., 2011; Gangodagamage et al., 2014; Wainwright et al., 2015; Nouwakpo et al., 2016). In this context, the authors point out that the small number of studies using laser scanning to consider changes in permafrost is still insufficient for an improved understanding of these frozen ground areas. To date, laser scanning data, has been primarily acquired by airborne systems in order to derive DEMs, which are analyzed coupled to remote sensing imagery and/or in situ measurements (e.g. Jones et al., 2015). Such ALS data typically has decimeter resolution (Barnhart and Crosby, 2013), and are not sufficiently accurate to study seasonal vertical movements of the ground caused by thawing and freezing processes of the permafrost which is usually in the order of a few $\mathrm{mm}$ to $\mathrm{cm}$. TLS monitoring is required to study such changes.

For TLS-based change detection and deformation analysis, one has to consider the following four main challenges: (1) local

30 variations in measurement geometry and surface properties, which means that parts of the surface might not be sampled in a repeated TLS survey, (2) registration errors, which can result in systematic shifts, (3) different viewpoints, which may lead to occlusion effects and (4) temporary objects (Lindenbergh and Pietrzyk, 2015). The sampling effect (challenge 1), is caused by various factors, such as vegetation height and density, as well as surface roughness and the scan setup. Due to occlusion effects (challenge 3) by solid objects the laser beam may not hit the ground at every point and, thus, the spatial sampling of the surface 
Earth Surf. Dynam. Discuss., https://doi.org/10.5194/esurf-2017-49

Manuscript under review for journal Earth Surf. Dynam.

Discussion started: 1 August 2017

(c) Author(s) 2017. CC BY 4.0 License.

of interest is never identical between two surveys (Lague et al., 2013). Furthermore, the monitoring setup with its incidence angles directly affecting penetration depths has an influence on the detectability of small-scale subsidence rates. The mentioned effects are relevant for quantifying subsidence in permafrost areas, which are dominated by e.g. organic matter, moss and shrubs and do not provide a stable ground surface. The highly dynamic nature of permafrost regions caused by freezing and thawing of the upper layer of the ground, is also challenging for the co-registration between two TLS surveys (challenge 2). The effect of elevation errors due to short ground vegetation is further described by Fan et al. (2014). An error of about 65\% of the grass height is reported. Lower incidence angles, i.e. the angle between surface normal and laser beam, for closer ground areas mean that it is easier for laser beams to penetrate through the vegetation to a lower level and to reach the ground surface below vegetation (Fan et al., 2014). Furthermore, Fan et al. (2014) conclude that (1) lower incidence angles (greater visibility)

10 reduce the occlusion effects, (2) scanning the same area from multiple locations reduces the vegetation error and (3) greater vegetation errors occur where vegetation is higher/denser. The effect of unfavorable scan geometries on soil erosion measurements is described by Eltner and Baumgart (2015). In a follow-up study, the authors utilize DEMs captured with an Unmanned Aerial System (UAS) to detect systematic errors in the TLS data and apply a selection to the point clouds with regards to scan geometry and surface roughness (Eltner et al., 2016). To the authors' knowledge, only a few studies have

15 evaluated the applicability of TLS for change detection in permafrost regions (Avian et al., 2008; Kociuba et al., 2014). Indepth analyses of the effect of vegetation, micro-topography and scan setup on TLS-based subsidence measurements are lacking.

With respect to deformation analyses in general, computing DEM difference rasters is a straightforward and commonly applied method to detect topographic surface changes (Abellán et al., 2009; Goodwin et al., 2016). Thereby, the 3D point cloud is

20 converted into a 2.5D representation of the surface which results in a loss of information (Lague et al., 2013). In recent years, calculating the differences directly within the point cloud has been gaining more and more attention. Barnhart and Crosby (2013) use cloud to mesh comparison (C2M) as well as Multiscale Model to Model Cloud Comparison (M3C2) developed by Lague et al. (2013) to detect surface changes on an evolving thermokarst in Alaska. They found that the M3C2 method is better suited to detect small-scale changes (down to $2-7 \mathrm{~cm}$ ) as the distance calculation algorithms accounts for position uncertainties,

25 i.e. random errors, due to averaging of point positions. Difference is then calculated along the local surface normal (Lague et al., 2013). Kromer et al. (2015) apply a modified M3C2 algorithm and relies on spatial and temporal averaging to detect displacements at sub-mm scale. In a follow-up study a near-real-time TLS monitoring system was evaluated for landslide monitoring (Kromer et al., 2017). However, TLS datasets with high temporal and spatial resolution are required for their presented 4D filtering approach, which is challenging in permafrost regions due to ground instability and extreme

30 meteorological conditions in these areas (Kociuba et al., 2014). The overall aim of this study is to evaluate TLS for deformation analyses in permafrost regions by comparing a raster-based and a point-cloud based approach with particular emphasis on the effect of tundra vegetation and micro-topography on $\mathrm{cm}$-scale subsidence monitoring. To account for sampling and signal occlusion effects, a new point-based filter strategy for multi-temporal deformation analyses is introduced. Further in-depth insights for TLS-based subsidence monitoring are reached by analyzing datasets of two different scan setups (repeating the 
Earth Surf. Dynam. Discuss., https://doi.org/10.5194/esurf-2017-49

Manuscript under review for journal Earth Surf. Dynam.

Discussion started: 1 August 2017

(c) Author(s) 2017. CC BY 4.0 License.

data acquisition from similar vs. different scan position). Finally, results are assessed based on a comparison to gold-standard manual subsidence measurements and on real-time kinematic (RTK) Global Navigation Satellite System (GNSS) measurements.

\section{Study area, field measurements and sensors}

5 Field work was carried out at the Trail Valley Creek (TVC) research watershed (68 $44^{\prime} 17^{\prime \prime} \mathrm{N} 133^{\circ} 26^{\prime} 26^{\prime \prime} \mathrm{W}$ ), located about $50 \mathrm{~km}$ North East of Inuvik, Northwest Territories, Canada (Fig. 1). TVC lies within the zone of continuous permafrost at the northern edge of the forest-tundra boundary region. Dominating vegetation is a mix of willow shrub (Salix) and herbaceous tundra with lichen (Lecidea) and mosses (Sphagnum) (Corns, 1974; Burn and Kokelj, 2009). The climate within this region is characterized by a strong seasonality with summer temperatures often above $20{ }^{\circ} \mathrm{C}$, and winter temperatures below $-40{ }^{\circ} \mathrm{C}$. At

10 the Inuvik, Meteorological Survey of Canada weather station, the average air temperature between the years 1971 and 2000 was about $-9{ }^{\circ} \mathrm{C}$ with a mean annual precipitation of $140 \mathrm{~mm}$ (Burn and Kokelj, 2009). For this study, two sites within TVC, each with different vegetation density, have been investigated: Site 1 is about $50 x 40 \mathrm{~m}$, almost flat and covered by low tundra vegetation and Site 2 is equal in size but contains more shrubs (Fig. 1).

High-resolution point cloud data in both test sites was captured using a Riegl VZ-400 TLS on June and August 2015 and

15 August 2016. This time-of-flight 3D laser scanner measures the distance between sensor and object, and calculates 3D coordinates $(\mathrm{x}, \mathrm{y}, \mathrm{z})$ for the captured object points. The resulting point clouds have a nominal point spacing of $3 \mathrm{~mm}$ at $10 \mathrm{~m}$ distance with a range accuracy of $5 \mathrm{~mm}$ at $100 \mathrm{~m}$ scanning range (RIEGL, 2014).

Within the two study sites, measurement of 43 ground validation points is repeated during each survey period using a highend RTK GNSS (Leica Viva GS15 receiver with GS10 base station). RTK is a relative positioning technique computing xyzcoordinates with a vertical accuracy of $15 \mathrm{~mm}$ and a horizontal one of $8 \mathrm{~mm}$ according to the manufacturer's datasheet (Leica Geosystems, 2015). These data will be used to evaluate TLS-based subsidence measurements (Brown et al., 2000).To prevent the RTK rover pole from sinking into the active layer and ensure comparable GNSS measurements on the moss and lichen covered soil, the rover setup is placed on a board made out of high pressure laminate. The validation points are marked so that the exact same positions were measured during each survey. Additionally, 24 carbon fiber rods for manual measurement of subsidence are installed. The rods are drilled about $1.8 \mathrm{~m}$ deep into the permafrost to prevent any movement induced by heave and subsidence as well as cryoturbation. With this setup, the so-called subsidence stations serve as absolute fixed points in the otherwise highly dynamic permafrost environment. Vertical movement of the ground surface is quantified by manually measuring the protruding part of the rods. Five measurements at each subsidence station are taken to account for microtopographic variations around the rod. Subsidence per station is assessed as median value of measurements, respectively.

30 However, it needs to be considered that measurements might not be consistent between the three survey dates as, for example, measurements were gathered by different persons and, though best practices are applied, recordings might vary slightly. As fixed points, the top of the carbon rods additionally serve to ensure high co-registration accuracy between the TLS datasets. 
Earth Surf. Dynam. Discuss., https://doi.org/10.5194/esurf-2017-49

Manuscript under review for journal Earth Surf. Dynam.

Discussion started: 1 August 2017

(c) Author(s) 2017. CC BY 4.0 License.

The three datasets from TLS, GNSS, and manual subsidence stations were captured during three field campaigns. For measuring seasonal subsidence rates, the first campaign took place at the beginning of the thawing period in June 2015 (2015/06/10 and 2015/06/11), the second campaign at the end of summer, in August 2015 (2015/08/21 and 2015/08/22). The following year, data acquisition was repeated in a third campaign in August 2016 (2016/08/23 and 2016/08/24), which enables

5 us to also quantify the change record of one entire year. Based on the captured datasets, deformation analysis is performed for the following three survey periods: 2015/06-2015/08, 2015/06-2016/08 and 2015/08-2016/08.

\section{Methods}

In this section we present and evaluate a method to extract subsidence rates in permafrost regions using TLS. Figure 2 shows the entire processing and analysis steps starting with data acquisition, co-registration of the single scan campaigns and pre-

10 processing of the derived point cloud. The main focus is on the deformation analysis using raster-based and point-based approaches to quantify small-scale vertical movements of the ground surface. To account for point sampling effects, filter strategies are applied before distances between the point clouds are calculated to derive deformation information.

\subsection{TLS data acquisition}

The two study sites are captured from seven scan positions during each TLS campaign (2015/06, 2015/08 and 2016/08). As

15 the scan setup, i.e. the incidence angle of the laser beam, has an impact on occlusion patterns (Fan et al., 2014; Lindenbergh and Pietrzyk, 2015), our method is evaluated for two different approaches: (1) TLS scans are repeated from the same scan positions (2015/08-2016/08) and, thus, the ground surface is scanned with similar incidence angles and (2) the surface is captured from different scan positions compared to the TLS survey before (2015/06-2015/08; 2015/06-2016/08). It has to be noted that with a non-stationary TLS setup it is not feasible to locate the laser scanner at the exact same position and height.

20 This results in a mean 3D distance between scan positions from 2015/08 and 2016/08 of about $20 \mathrm{~cm}$ (min. $14 \mathrm{~cm}$, max. $29 \mathrm{~cm})$.

\subsection{Registration and co-registration}

First, the TLS point clouds are registered and georeferenced in the RiSCAN PRO software (RIEGL). The single scans of each survey are registered based on four cylindrical reflectors that are placed at the edges of the study sites. 3D distances between the single, registered scan positions are on mm-scale at the reflector tie points (Appendix 1). Then, the registered point cloud is georeferenced into a common global coordinates system (WGS 1984, UTM 8N) using the reflectors' coordinates captured via the RTK GNSS system.

To achieve a highly accurate registration of the three different TLS campaigns, subsequent co-registration of the georeferenced point clouds is performed based on the stable subsidence stations. Five to seven coordinate pairs (top of the rods) are extracted for each study site and used to calculate a rigid 3D transformation matrix which maintains the relative point positions. Quality 
Earth Surf. Dynam. Discuss., https://doi.org/10.5194/esurf-2017-49

Manuscript under review for journal Earth Surf. Dynam.

Discussion started: 1 August 2017

(c) Author(s) 2017. CC BY 4.0 License.

of co-registration is evaluated based on 10 control coordinate pairs: Co-registration reduces the RMSE of the z-distances between the TLS surveys to $0.2-0.3 \mathrm{~cm}$ at the control points (Table 1). Uncertainties for the TLS-derived change maps are assumed to be in the magnitude of the co-registration error in z-direction (Orem and Pelletier, 2015). Thus, prerequisites are met for quantifying small-scale vertical changes within our study sites.

\section{$5 \quad$ 3.3 Pre-processing}

Pre-processing of the TLS datasets includes filtering of the datasets to a maximum range of $30 \mathrm{~m}$ around the scan positions in order to avoid alignment errors that increase with large distance to the respective scan position. Furthermore, spatially isolated points are removed via a statistical outlier filter (settings: number of neighbors, 10; standard deviation multiplier threshold, 1; Rusu and Cousins, 2011). Point clouds are then further processed using OPALS (version 2.1.5; Pfeifer et al., 2014), Point

10 Cloud Library (PCL) (Rusu and Cousins, 2011) and in CloudCompare (version 2.7.0).

For subsequent analyses, incidence angles of the laser beam are calculated for each TLS point. The incidence angle is defined as the angle between surface normal and incoming laser beam. Given the horizontal character of the study sites, the surface normal is assumed to be orthogonal to the horizontal plane for every point.

One critical point for quantifying ground movements in Arctic regions is to properly identify the actual ground surface. In

15 tundra environments, this seemingly simple decision is complicated by the fact that the mineral soil is typically covered by a thick moss- lichen layer, as well as vascular plants. This moss-lichen surface is typically rather porous, and varies in height at very small scales. In this study, we define the ground surface as the solid moss-lichen surface that covers the underlying mineral layers. For excluding laser points that originate from and vascular vegetation that is above the ground surface, Bremer and Sass (2012) report that most surface-based vegetation filters do not achieve satisfying results for dense shrub vegetation.

20 Thus, we follow the local minimum approach and extract ground points based on the criterion: lowest z-value within a defined neighborhood. Optimal search radius for identifying local neighbors is evaluated based on the GNSS ground measurements and is set to $2.5 \mathrm{~cm}$. Subsidence is quantified by calculating ground surface elevation differences between two survey dates, assuming that the thickness of the moss-lichen layer does not change significantly

To analyze the effect of vegetation on the deformation analysis, we calculate different measures to describe vegetation characteristics, such as range of z-values per pixel cell and RMS of z-values. Micro-topographic characteristics are considered by extracting local depressions within the study sites. Local depressions are identified by selecting the local minimum within a $2 \mathrm{D}$ search radius of $0.5 \mathrm{~m}$.

\subsection{Vertical deformation analysis}

For quantifying vertical movements of the ground surface that occur between the TLS surveys, we compare DEM differencing 30 as a raster-based approach (e.g. Abellán et al. (2009), Goodwin et al. (2016)) with a point-based approach (Lague et al., 2013). The existing workflows are extended by a selection step that aims at identifying suitable ground surface points for the deformation analysis. Thereby we build on the finding that elevation errors due to (short) ground vegetation can be reduced 
Earth Surf. Dynam. Discuss., https://doi.org/10.5194/esurf-2017-49

Manuscript under review for journal Earth Surf. Dynam.

Discussion started: 1 August 2017

(c) Author(s) 2017. CC BY 4.0 License.

by capturing the area from multiple scan positions (Fan et al., 2014). To get further insights and validate our method, deformation analysis is performed based on (1) all ground surface TLS points and (2) after selecting those ground surface TLS points with neighboring points from other scan positions, i.e. locations that have been seen from multiple scan positions.

\subsubsection{DEM differencing}

5 In this study, firstly, DEMs are generated based on the lowest z-value within each raster cell and evaluated using the GNSS ground measurements. Within this comparison different TLS raster cell sizes (from $1 \mathrm{~cm}$ up to $500 \mathrm{~cm}$ ) are evaluated to find the best compromise between capturing small-scale topographic variabilities and removing non-ground points from the TLS datasets. Secondly, we assess the quality of raster-based subsidence monitoring using difference DEMs.

\subsubsection{M3C2 distance calculation}

10 Compared to the raster-based approach, point-based approaches for deformation analyses incorporate the full 3D information. We use the M3C2 distance calculation algorithm presented by Lague et al. (2013) to determine ground movements between the three survey dates. Main advantage of this method is that it accounts for position uncertainties, i.e. random errors due to averaging of point positions (Barnhart and Crosby, 2013). The M3C2 algorithm consist of two parts: Firstly, point normal estimation is performed and secondly, differences are calculated. For performing the M3C2 analysis, we fixed the normal in

15 vertical direction, as the focus of this study in on vertical ground surface changes. The parameter projection scale set to $0.1 \mathrm{~m}$, and the maximum displacement distance to $1.0 \mathrm{~m}$. Significance of change rates is calculated by taking the (co-)registration error and local surface roughness into account (Lague et al., 2013). According to Abellan et al. (2016), the M3C2 algorithm has gained wide acceptance and Barnhart and Crosby (2013) state that it is the better tool (compared to e.g. direct cloud to cloud comparison) to resolve small changes.

\section{$20 \quad 3.4 .3 \quad$ Point filter strategies}

To account for sampling effects, two filter strategies are introduced that are applied to the TLS point clouds of each survey period before $\mathrm{M} 3 \mathrm{C} 2$ distances are calculated. We aim at identifying positions within the point cloud that are "visible" from more than one scan position. Visibility is met if within a defined threshold around one position, a TLS point from another scan position can be found. The 3D search distance $\left(\mathrm{r}_{\mathrm{sp}}\right)$ for the visibility check is set to $0.5 \mathrm{~cm}$ to account for TLS position uncertainties. We investigate and compare two different filter strategies, which are the following (Fig. 3):

(1) Select TLS point from TLS ground surface points if visible from multiple scan positions.

(2) Select TLS point from all TLS points (and not from the TLS ground surface point only) if visible from multiple scan position. Then, select the local minima from all visible TLS points (within an infinite vertical cylinder, $r_{\min }=2.5 \mathrm{~cm}$ ).

Thus, with strategy 2, firstly, all positions are selected that are visible from more than one scan position. Secondly, the local minima of those points are extracted. We expect filter strategy 1 to be the more rigorous criterion resulting in a reduced number of points available for the deformation analysis. In contrast, strategy 2 retains more TLS points, but deformation rates might 
Earth Surf. Dynam. Discuss., https://doi.org/10.5194/esurf-2017-49

Manuscript under review for journal Earth Surf. Dynam.

Discussion started: 1 August 2017

(c) Author(s) 2017. CC BY 4.0 License.

be less reliable. Once the relevant points are selected in each TLS dataset, the M3C2 distances are calculated to quantify the vertical movements.

The search radius $r_{\min }$ is set to $2.5 \mathrm{~cm}$, considering the GNSS-based DEM validation (Section 4.1.1 DEM accuracy assessment for details). The 3D search radius $r_{\mathrm{sp}}$ is set to $1 \mathrm{~cm}$. To account for position uncertainties of the TLS a threshold of $0.5 \mathrm{~cm}$ is

5 chosen to select the local minima (i.e. the lowest point within a vertical search cylinder is selected as well as all points with zdistance $<0.5 \mathrm{~cm}$ to the lowest point).

\subsection{Quality assessment}

Standard measures for comparing laser scanning data with a validation dataset (e.g. GNSS measurements) are, for example, the root-mean-square error (RMSE), the mean error and the standard deviation (std.) of error. Furthermore, we calculate robust

10 accuracy measures, which take outlier values and non-normal error distributions into account (i.e. median, normalized median absolute deviation [NMAD], 68.3\% and 95\% quantile) (Hämmerle et al., 2016; Höhle and Höhle, 2009).

\section{Results and discussion}

\subsection{Raster-based deformation analysis}

\subsubsection{DEM accuracy assessment}

15 The derived DEMs are validated using the GNSS ground measurements. We test cell sizes between 1 and $500 \mathrm{~cm}$ and find a resolution of $5 \mathrm{~cm}$ to be the best compromise between capturing small-scale topographic variabilities and removing non-ground points from the TLS datasets (Figure 4, and Appendix 2): The median error of height differences between TLS and GNSS is $0.1 \mathrm{~cm}$ up to $0.8 \mathrm{~cm}$ for the three survey periods (cell size $=5 \mathrm{~cm}$ ). The robust estimator of standard deviation, the NMAD, ranges between 0.8 and $4.1 \mathrm{~cm}$ and the RMSE varies between 1.5 and $4.3 \mathrm{~cm}$ (Appendix 3). For small cell sizes $(<5 \mathrm{~cm})$ the

20 TLS elevation values are higher than those measured with the GNSS.

\subsubsection{Difference DEMs}

Area-wide difference rasters are obtained by subtracting the TLS DEMs of two survey dates (cell size $=5 \mathrm{~cm}$ ). The average TLS-based vertical change rate at site 1 for the periods 2015/06-2015/08 and 2015/06-2016/08 is about $-2 \mathrm{~cm}(\mathrm{std} .=7 \mathrm{~cm}$ ), and at mm-level (std. $=4 \mathrm{~cm}$ ) between 2015/08 and 2016/08. At site 2 the extracted values suggest that the seasonal subsidence rates are lower compared to site 1 (about $1 \mathrm{~cm}$ between 2015/06-2015/08, std. $=7 \mathrm{~cm}$ ).

However, in the difference maps the effect of the scanning setup on the multi-temporal comparison becomes visible (Figure 5). For the comparison between 2015/06-2015/08 and 2015/06-2016/08 (i.e. data acquisition is repeated from different scan positions) negative change rates next to the scan positions of August 2015 and August 2016, respectively, seem to be an overestimation of change. Next to scan positions of June 2015 the opposite effect is detected, which would indicate that change 
Earth Surf. Dynam. Discuss., https://doi.org/10.5194/esurf-2017-49

Manuscript under review for journal Earth Surf. Dynam.

Discussion started: 1 August 2017

(c) Author(s) 2017. CC BY 4.0 License.

rates are positive (i.e. an artificial heave is detected). Following our hypothesis in correspondence with Fan et al. (2014), this is caused due to the comparison of areas that have been captured at different incidence angles, meaning that the sampling differs between the two surveys (Fan et al. 2014). If the area is captured from similar scan positions (2015/08-2016/08), this effect is less dominant as shown in Figure 5(d). Nevertheless, it is noticeable that the difference map shows higher change rates (on cm-level) next to the scan positions compared to areas at further distance.

Further in-situ measurements are considered for evaluating the results. Compared to measurements at the subsidence stations, TLS-based difference DEMs tend to show smaller subsidence rates (median error between TLS and subsidence stations up to $-1.2 \mathrm{~cm}$, Appendix 4). All in all, this reveals a significant limitation of TLS DEM differencing for detecting spatial patterns of small-scale subsidence.

\section{$10 \quad 4.2$ Point-based deformation analysis}

\subsubsection{Vertical changes}

Vertical changes between point clouds of two surveys are derived using the M3C2 distance calculation. Figure 6 shows the resulting change maps for site 1 (seasonal subsidence rates, survey 2015/06 to 2015/08) based on (1) all TLS $\min$ points, (2) $\mathrm{TLS}_{\text {min }}$ points that are illuminated by more than one scan position (strategy 1) and (3) local minima of those TLS points that

15 are visible from at least two scan positions (strategy 2). For a map displaying the changes for site 2 see Appendix 5. Whereas the sampling effect is visible when no selection is applied, filter strategy 1 masks out the affected areas and reduces the total

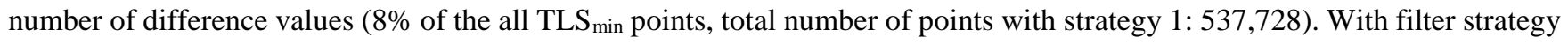
2 the number of points representing vertical changes is $53 \%$ of the unselected dataset (total number: $3,532,408$ ). Figure 6(c) visualizes that the sampling effect is less dominant when applying point selection. It needs to be noted that regarding the mean

20 and median of change the filter strategies differ at mm-scale only. However, standard deviation and value range of changes is reduced by more than $50 \%$ with filter strategy 1 . We confirm these findings by plotting change rate against incidence angle in Figure 7. While the incidence angle effects change rates if the deformation analysis relies on the entire TLS min $_{\text {dataset, applying }}$ filter strategy 1 reduces the sampling effect. However, with higher incidence angles i.e. larger distance to the scan positions, a wider scattering of the change rates occur. A larger (vegetation) error is also reported by Fan et al. (2014) with increasing scan distance (and incidence angle). In this study within the pre-processing we filter the TLS dataset to a maximum distance of $30 \mathrm{~m}$ to the scan positions. A severer distance or incidence angle filter would allow reducing more noise (Fig. 7: filter strategy 1), but is a trade-off against number of available TLS points and, thus, the total area for which change rates can be derived. Taking the difference maps into account confirms that the applied filter strategies are suitable for reducing the detected overand underestimation of change rates and, thus, the observed sampling effects. In summary, the findings lead to the conclusion

30 that the selection of TLS points that are visible from multiple scan positions allows for revealing small-scale spatial change patterns that are not influenced by sampling effects. 
Earth Surf. Dynam. Discuss., https://doi.org/10.5194/esurf-2017-49

Manuscript under review for journal Earth Surf. Dynam.

Discussion started: 1 August 2017

(c) Author(s) 2017. CC BY 4.0 License.

The result presented above is confirmed by analyzing the changes within site 2 and, further, by taking into account the survey period of 2015/06 to 2016/08 as additional reference (Table 2): The statistics show that standard deviation of differences is reduced by $22 \%$ up to $58 \%$ for filter strategy 1 and by $10 \%$ up to $25 \%$ for strategy 2 . On plot-level the median subsidence rates are consistent for the three survey periods at both sides. Change rates at site 2 tend to be lower (on mm-scale), whereas standard

5 deviation of differences with point selection is higher (up to $1.4 \mathrm{~cm}$ ) compared to site 1 . This can indicate an influence of sitespecific characteristics (e.g. vegetation height) on the deformation analysis.

By comparing TLS point clouds captured in August 2015 and 2016, an annual median subsidence rate of $-0.4 \mathrm{~cm}$ is detected. TLS data were captured from similar scan positions according to scan setup 2. Again, both filter strategies are applied to both TLS point clouds: Filter strategy 1 and 2 reduce the number of difference values by a similar percentage as with scan setup 1

10 (down to approx. $10 \%$ with filter strategy 1, and approx. $50 \%$ with strategy 2). Furthermore, the $95^{\text {th }}$ percentile is lower compared to performing the comparison analysis based on all TLS $S_{\min }$ points.

The visual evaluation of the resulting change maps for site 1, survey period 2015/08-2016/08 (Appendix 6) confirms that areas showing high subsidence or heave rates are masked out by filter strategy 1 and partly also by strategy 2 . Based on the presented results we conclude that strategy 1 leads to a more rigorous selection compared to strategy 2 i.e. less points are selected by

15 strategy 1 compared to strategy 2 . Both approaches reduce the sampling effect in the multi-temporal deformation analyses, not only if data acquisition is repeated from different but also from the same scan position.

\subsubsection{Comparison with manual subsidence stations}

TLS-based change rates are compared with in-situ measurements gathered manually at the subsidence stations. These stations provide 12 change measurements per site. For comparison, more than 6 million data points are retrieved from the TLS datasets

20 (leading to about 500,000 difference measurements when applying the more rigorous filter strategy 1). For each subsidence station the closest TLS change rate is extracted. Differences between the change rates at the subsidence stations are presented in Figure 8 for site 1 (Appendix 7 for site 2). For the survey period 2015/06-2015/08, the median and the RMSE is reduced by applying the filter strategies. This finding cannot be confirmed for the survey periods 2015/06-2016/08 and 2015/08-2016/08. For those survey periods, manual measurements using subsidence stations show higher subsidence rates. Furthermore,

25 applying the filter strategy does not decrease the RMSE. One explanation could be uncertainties that might be introduced when measuring subsidence manually at subsidence stations (see section Study area, field measurements and sensors for more details). Another point is the spatial sampling of the subsidence stations, which are placed in areas of sparse vegetation that are visible from various scan positions and, thus, being little affected by occlusion effects. Further research is needed to better understand the uncertainties of manually measured subsidence rates and its implication of methodological differences in monitoring subsidence compared to TLS or other remote sensing techniques. 
Earth Surf. Dynam. Discuss., https://doi.org/10.5194/esurf-2017-49

Manuscript under review for journal Earth Surf. Dynam.

Discussion started: 1 August 2017

(c) Author(s) 2017. CC BY 4.0 License.

\subsubsection{Effect of vegetation and micro-topography}

Fan et al. (2014) describe errors that occur in TLS ground measurements due to short vegetation. Another major concern in TLS deformation analysis are uncertainties due to surface roughness (Barnhart and Crosby, 2013). In the following, we analyze the effect of the presented point selection workflow on areas that are considered to influence TLS-derived change rates due to their vegetation and micro-topographic characteristics (e.g. dense/high vegetation). This is done exemplarily for site 1 , survey period 2015/06-2015/08. Figure 9 shows site 1 and the areas selected by filter strategy 1, local depressions and vegetation heights. Whereas without point selection the percentage of pixels representing local depressions is $20 \%$, the percentage is reduced to $10 \%$ by applying filter strategy 1 . When looking at the distribution of vegetation heights (i.e. range of $\mathrm{z}$-values) within areas selected by filter strategy 1 , we find a medium height of $9.5 \mathrm{~cm}$ compared to $13 \mathrm{~cm}$ in areas that are masked out.

10 Standard deviation of vegetation heights is $7.8 \mathrm{~cm}$ in the included areas compared to $18 \mathrm{~cm}$ in the excluded areas (Appendix 8 for more details). These findings, firstly, confirm that vegetation does have an influence on TLS-based subsidence monitoring. This effect tends to increase in areas covered by higher and/or denser vegetation which aligns with e.g. Fan et al. (2014). Likewise in local depressions the sampling effects tends to be more dominant. Secondly, we show that the presented filter strategies can be used to mask out such areas from the deformation analysis by taking indirectly the scan setup into account and without requiring any a priori knowledge.

\section{Conclusions}

In this study we show that if the ground surface is captured by more than one TLS scan position, plausible subsidence rates (up to mm-scale) can be derived; compared to e.g. standard raster-based DEM difference maps which contain change rates strongly affected by sampling and occlusion effects. While those effects emerge in the standard difference maps, the average subsidence rates on plot-level are consistent with the applied calculation methods: seasonal subsidence is about $-2 \mathrm{~cm}$ (2015/06-2015/08) and approx. -0.5 cm over one entire year (2015/08-2016/08) at our two study sites.

Overall, the limitations of DEM differencing and point-based distance calculation based on TLS for monitoring small-scale vertical movements are presented. This effect has special relevance in Arctic tundra ecosystems due to a dense moss-lichen layer, which covers the underlying organic and soil layers, and, against this background, occurs even if data acquisition is

25 repeated from similar scan positions. Besides spatial sampling and occlusion effects, position and co-registration uncertainties influence quantification of small-scale changes.

Accordingly, we recommend the following to maximize the accuracy of TLS based subsidence monitoring:

(i) Co-registration is an important prerequisite to enable quantification of vertical changes on $\mathrm{mm} / \mathrm{cm}$-scale. Systematic shifts between multi-temporal TLS datasets can be reduced based on permanent fix points in an otherwise highly dynamic permafrost environment, for example, by applying a rigid 3D transformation. 
Earth Surf. Dynam. Discuss., https://doi.org/10.5194/esurf-2017-49

Manuscript under review for journal Earth Surf. Dynam.

Discussion started: 1 August 2017

(c) Author(s) 2017. CC BY 4.0 License.

(c) (i)

(ii) Position averaging methods, such as the $\mathrm{M} 3 \mathrm{C} 2$ distance calculation algorithm, allow for minimizing position uncertainties. However, spatial sampling effects do influence the deformation analysis, especially if the ground is covered by dense/high vegetation and in local depressions.

(iii) Scanning the area of interest from multiple scan positions reduces this effect.

5 (iv) Following this, TLS point suitable for multi-temporal change deformation, i.e. point positions that are visible from multiple scan positions, which can be identified by the introduced point filter strategy 1 .

Thus, the proposed method allows us to identify locations for which plausible subsidence rates (up to mm-scale) can be derived, compared to e.g. standard DEM difference maps which contain change rates strongly affected by sampling effects. This information is important to gain a deeper understanding of permafrost-related subsidence processes. Furthermore, it provides highly accurate ground-truth data which is needed for further developing area-wide subsidence monitoring methods, for example, from space using SAR interferometry

\section{Author contributions}

All authors worked on the idea and the framework of this study. K. Anders, I. Beck, J. Boike, B. Höfle, S. Marx and M. Langer collected field data. S. Marx and K. Anders implemented the data analysis scripts and conducted all analyses. S. Marx prepared

15 the manuscript with contributions from all co-authors.

\section{Competing interests}

The authors declare that they have no conflict of interest.

\section{Acknowledgement}

This work was funded by the Federal Ministry of Economics and Technology (BMWi) and the German Aerospace Center

20 (DLR), Germany in the framework of the project PermaSAR (FKZ: 50EE1418). Support from the Wilfrid Laurier Cold Regions Research Centre (CCRC) to use the Laurier TVC field camp is greatly appreciated. 
Earth Surf. Dynam. Discuss., https://doi.org/10.5194/esurf-2017-49

Manuscript under review for journal Earth Surf. Dynam.

Discussion started: 1 August 2017

(c) Author(s) 2017. CC BY 4.0 License.

\section{References}

Abellan, A., Derron, M.-H., and Jaboyedoff, M.: Use of 3D Point Clouds in Geohazards: Special Issue: Current Challenges and Future Trends, Remote Sensing, 8, 130, doi:10.3390/rs8020130, 2016.

Abellán, A., Jaboyedoff, M., Oppikofer, T., and Vilaplana, J. M.: Detection of millimetric deformation using a terrestrial laser scanner: Experiment and application to a rockfall event, Nat. Hazards Earth Syst. Sci., 9, 365-372, doi:10.5194/nhess-9-365-2009, 2009.

Antonova, S., Kääb, A., Heim, B., Langer, M., and Boike, J.: Spatio-temporal variability of X-band radar backscatter and coherence over the Lena River Delta, Siberia, Remote Sensing of Environment, 182, 169-191, doi:10.1016/j.rse.2016.05.003, 2016.

10 Arenson, L. U., Kääb, A., and O'Sullivan, A.: Detection and Analysis of Ground Deformation in Permafrost Environments, Permafrost and Periglac. Process., 27, 339-351, doi:10.1002/ppp.1932, 2016.

Avian, M., Kellerer-Pirklbauer, A., and Bauer, A.: Remote Sensing Data for Monitoring Periglacial Processes in Permafrost Areas: Terrestrial Laser Scanning at the Hinteres Langtalkar Rock Glacier, Austria, in: Ninth International Conference on Permafrost, Fairbanks, Alaska, United States, 2008.

15 Avian, M., Kellerer-Pirklbauer, A., and Bauer, A.: LiDAR for monitoring mass movements in permafrost environments at the cirque Hinteres Langtal, Austria, between 2000 and 2008, Nat. Hazards Earth Syst. Sci., 9, 1087-1094, doi:10.5194/nhess-9-1087-2009, 2009.

Barnhart, T. and Crosby, B.: Comparing Two Methods of Surface Change Detection on an Evolving Thermokarst Using High-Temporal-Frequency Terrestrial Laser Scanning, Selawik River, Alaska, Remote Sensing, 5, 2813-2837, doi:10.3390/rs5062813, 2013.

Beck, I., Ludwig, R., Bernier, M., Strozzi, T., and Boike, J.: Vertical movements of frost mounds in subarctic permafrost regions analyzed using geodetic survey and satellite interferometry, Earth Surf. Dynam., 3, 409-421, doi:10.5194/esurf3-409-2015, 2015.

Bhardwaj, A., Sam, L., Bhardwaj, A., and Martín-Torres, F. J.: LiDAR remote sensing of the cryosphere: Present applications and future prospects, Remote Sensing of Environment, 177, 125-143, doi:10.1016/j.rse.2016.02.031, 2016.

Bodin, X., Schoeneich, P., and Jaillet, S.: High-Resolution DEM Extraction from Terrestrial LIDAR Topometry and Surface Kinematics of the Creeping Alpine Permafrost: The Laurichard Rock Glacier Case Study (Southern French Alps), in: Ninth International Conference on Permafrost, Fairbanks, Alaska, United States, 137-142, 2008.

Bremer, M. and Sass, O.: Combining airborne and terrestrial laser scanning for quantifying erosion and deposition by a debris flow event, Geomorphology, 138, 49-60, doi:10.1016/j.geomorph.2011.08.024, 2012.

Brown, J., Hinkel, K. M., and Nelson, F. E.: The circumpolar active layer monitoring (calm) program: Research designs and initial results 1, Polar Geography, 24, 166-258, doi:10.1080/10889370009377698, 2000. 
Earth Surf. Dynam. Discuss., https://doi.org/10.5194/esurf-2017-49

Manuscript under review for journal Earth Surf. Dynam.

Discussion started: 1 August 2017

(c) Author(s) 2017. CC BY 4.0 License.

Burn, C. R. and Kokelj, S. V.: The environment and permafrost of the Mackenzie Delta area, Permafrost Periglac. Process., 20, 83-105, doi:10.1002/ppp.655, 2009.

Chasmer, L., Hopkinson, C., Petrone, R., and Quinton, W.: Fusion of airborne LiDAR and WorldView-2 MS data for classification of depth to permafrost within Canada's sub-Arctic, in: SilviLaser, Hobart, Tasmania, 2011.

5 CloudCompare: (version 2.7.0): [GPL software]: http://www.cloudcompare.org/.

Corns, I. G. W.: Arctic plant communities east of the Mackenzie Delta, Can. J. Bot., 52, 1731-1745, doi:10.1139/b74-225, 1974.

Deline, P., Jaillet, S., Rabatel, A., and Ravanel, L.: Ground-Based LiDAR data on permafrost-related rock fall activity in the Mont-Blanc massif, in: Ninth International Conference on Permafrost, Fairbanks, Alaska, United States, 349-354, 2008.

Eltner, A. and Baumgart, P.: Accuracy constraints of terrestrial Lidar data for soil erosion measurement: Application to a Mediterranean field plot, Geomorphology, 245, 243-254, doi:10.1016/j.geomorph.2015.06.008, 2015.

Eltner, A., Schneider, D., and Maas, H.-G.: Integrated processing of high resolution topographic data for soil erosion assessment, Int. Arch. Photogramm. Remote Sens. Spatial Inf. Sci., XLI-B5, 813-819, doi:10.5194/isprs-archives-XLIB5-813-2016, 2016.

15 Fan, L., Powrie, W., Smethurst, J., Atkinson, P. M., and Einstein, H.: The effect of short ground vegetation on terrestrial laser scans at a local scale, ISPRS Journal of Photogrammetry and Remote Sensing, 95, 42-52, doi:10.1016/j.isprsjprs.2014.06.003, 2014.

Gangodagamage, C., Rowland, J. C., Hubbard, S. S., Brumby, S. P., Liljedahl, A. K., Wainwright, H., Wilson, C. J., Altmann, G. L., Dafflon, B., Peterson, J., Ulrich, C., Tweedie, C. E., and Wullschleger, S. D.: Extrapolating active layer thickness measurements across Arctic polygonal terrain using LiDAR and NDVI data sets, Water resources research, 50, 6339-6357, doi:10.1002/2013WR014283, 2014.

Goodwin, N. R., Armston, J., Stiller, I., and Muir, J.: Assessing the repeatability of terrestrial laser scanning for monitoring gully topography: A case study from Aratula, Queensland, Australia, Geomorphology, 262, 24-36, doi:10.1016/j.geomorph.2016.03.007, 2016.

25 Günther, F., Overduin, P. P., Yakshina, I. A., Opel, T., Baranskaya, A. V., and Grigoriev, M. N.: Observing Muostakh disappear: Permafrost thaw subsidence and erosion of a ground-ice-rich island in response to arctic summer warming and sea ice reduction, The Cryosphere, 9, 151-178, doi:10.5194/tc-9-151-2015, 2015.

Hämmerle, M., Schütt, F., and Höfle, B.: Terrestrial and unmanned aerial system imagery for deriving photogrammetric three-dimensional point clouds and volume models of mass wasting sites, J. Appl. Remote Sens, 10, 26029, doi:10.1117/1.JRS.10.026029, 2016.

Höfle, B. and Rutzinger, M.: Topographic airborne LiDAR in geomorphology: A technological perspective, Zeit fur Geo Supp, 55, 1-29, doi:10.1127/0372-8854/2011/0055S2-0043, 2011.

Höhle, J. and Höhle, M.: Accuracy assessment of digital elevation models by means of robust statistical methods, ISPRS Journal of Photogrammetry and Remote Sensing, 64, 398-406, doi:10.1016/j.isprsjprs.2009.02.003, 2009. 
Earth Surf. Dynam. Discuss., https://doi.org/10.5194/esurf-2017-49

Manuscript under review for journal Earth Surf. Dynam.

Discussion started: 1 August 2017

(c) Author(s) 2017. CC BY 4.0 License.

Hubbard, S. S., Gangodagamage, C., Dafflon, B., Wainwright, H., Peterson, J., Gusmeroli, A., Ulrich, C., Wu, Y., Wilson, C., Rowland, J., Tweedie, C., and Wullschleger, S. D.: Quantifying and relating land-surface and subsurface variability in permafrost environments using LiDAR and surface geophysical datasets, Hydrogeol J, 21, 149-169, doi:10.1007/s10040-012-0939-y, 2013.

5 IPCC: Climate Change 2013 - The Physical Science Basis: Contribution of Working Group I to the Fifth Assessment Report of the Intergovernmental Panel on Climate Change, Cambridge, United Kingdom and New York, NY, USA, 1535 pp., 2013.

Jones, B. M., Grosse, G., Arp, C. D., Miller, E., Liu, L., Hayes, D. J., and Larsen, C. F.: Recent Arctic tundra fire initiates widespread thermokarst development, Scientific reports, 5, 15865, doi:10.1038/srep15865, 2015.

10 Kociuba, W., Kubisz, W., and Zagórski, P.: Use of terrestrial laser scanning (TLS) for monitoring and modelling of geomorphic processes and phenomena at a small and medium spatial scale in Polar environment (Scott River — Spitsbergen), Geomorphology, 212, 84-96, doi:10.1016/j.geomorph.2013.02.003, 2014.

Kromer, R., Abellán, A., Hutchinson, D., Lato, M., Edwards, T., and Jaboyedoff, M.: A 4D Filtering and Calibration Technique for Small-Scale Point Cloud Change Detection with a Terrestrial Laser Scanner, Remote Sensing, 7, 1302913052, doi:10.3390/rs71013029, 2015.

Kromer, R. A., Abellán, A., Hutchinson, D. J., Lato, M., Chanut, M.-A., Dubois, L., and Jaboyedoff, M.: Automated terrestrial laser scanning with near-real-time change detection - monitoring of the Séchilienne landslide, Earth Surf. Dynam., 5, 293-310, doi:10.5194/esurf-5-293-2017, 2017.

Lague, D., Brodu, N., and Leroux, J.: Accurate 3D comparison of complex topography with terrestrial laser scanner: Application to the Rangitikei canyon (N-Z), ISPRS Journal of Photogrammetry and Remote Sensing, 82, 10-26, doi:10.1016/j.isprsjprs.2013.04.009, 2013.

Leica Geosystems: Leica Viva GS15: Data sheet: http://w3.leicageosystems.com/downloads123/zz/gpsgis/viva\%20gs15/brochures-datasheet/leica_viva_gs15_ds_en.pdf.

Lindenbergh, R. and Pietrzyk, P.: Change detection and deformation analysis using static and mobile laser scanning, Appl Geomat, 7, 65-74, doi:10.1007/s12518-014-0151-y, 2015.

Little, J. D., Sandall, H., Walegur, M. T., and Nelson, F. E.: Application of differential global positioning systems to monitor frost heave and thaw settlement in tundra environments, Permafrost Periglac. Process., 14, 349-357, doi:10.1002/ppp.466, 2003.

Liu, L., Zhang, T., and Wahr, J.: InSAR measurements of surface deformation over permafrost on the North Slope of Alaska, J. Geophys. Res., 115, 61, doi:10.1029/2009JF001547, 2010.

Melnikov, P. I.: Vliyanie podzemnykh vod na glubokoe okhlazhdenie verkhnej zony zemnoj kory (Influence of ground waters on the deep cooling of upper Earth crust). Merzlotno-gidrogeologicheskie i gidrogeotermicheskie issledovaniya na vostoke SSSR (Cryo-hydrogeological and hydrogeothermal investigations in the East of USSR)., Nauka, $24-29,1967$. 
Earth Surf. Dynam. Discuss., https://doi.org/10.5194/esurf-2017-49

Manuscript under review for journal Earth Surf. Dynam.

Discussion started: 1 August 2017

(c) Author(s) 2017. CC BY 4.0 License.

Nixon, M., Tarnocai, C., and Kutny, L.: Long-term active layer monitoring: Mackenzie Valley, northwest Canada, in: Eigth International Conference on Permafrost, Zurich, CH, 821-826, 2003.

Nouwakpo, S. K., Weltz, M. A., and McGwire, K.: Assessing the performance of structure-from-motion photogrammetry and terrestrial LiDAR for reconstructing soil surface microtopography of naturally vegetated plots, Earth Surf. Process. Landforms, 41, 308-322, doi:10.1002/esp.3787, 2016.

Orem, C. A. and Pelletier, J. D.: Quantifying the time scale of elevated geomorphic response following wildfires using multitemporal LiDAR data: An example from the Las Conchas fire, Jemez Mountains, New Mexico, Geomorphology, 232, 224-238, doi:10.1016/j.geomorph.2015.01.006, 2015.

Pfeifer, N., Mandlburger, G., Otepka, J., and Karel, W.: OPALS - A framework for Airborne Laser Scanning data analysis, Computers, Environment and Urban Systems, 45, 125-136, doi:10.1016/j.compenvurbsys.2013.11.002, 2014.

RIEGL: RiSCAN PRO: http://www.riegl.com/products/software-packages/riscan-pro/.

RIEGL: Datasheet RIEGL VZ-400: http://www.riegl.com/uploads/tx_pxpriegldownloads/10_DataSheet_VZ-400_2014-0919.pdf, last access: 17 November 2014.

Rowland, J. C., Jones, C. E., Altmann, G., Bryan, R., Crosby, B. T., Hinzman, L. D., Kane, D. L., Lawrence, D. M., Mancino, A., Marsh, P., McNamara, J. P., Romanvosky, V. E., Toniolo, H., Travis, B. J., Trochim, E., Wilson, C. J., and Geernaert, G. L.: Arctic Landscapes in Transition: Responses to Thawing Permafrost, Eos Trans. AGU, 91, 229-230, doi:10.1029/2010EO260001, 2010.

Rusu, R. B. and Cousins, S.: 3D is here: Point Cloud Library (PCL), in: IEEE International Conference on Robotics and Automation (ICRA), Shanghai, China, 2011.

Shiklomanov, N. I., Streletskiy, D. A., Little, J. D., and Nelson, F. E.: Isotropic thaw subsidence in undisturbed permafrost landscapes, Geophys. Res. Lett., 40, 6356-6361, doi:10.1002/2013GL058295, 2013.

Short, N., Brisco, B., Couture, N., Pollard, W., Murnaghan, K., and Budkewitsch, P.: A comparison of TerraSAR-X, RADARSAT-2 and ALOS-PALSAR interferometry for monitoring permafrost environments, case study from Herschel Island, Canada, Remote Sensing of Environment, 115, 3491-3506, doi:10.1016/j.rse.2011.08.012, 2011.

Short, N., LeBlanc, A.-M., Sladen, W., Oldenborger, G., Mathon-Dufour, V., and Brisco, B.: RADARSAT-2 D-InSAR for ground displacement in permafrost terrain, validation from Iqaluit Airport, Baffin Island, Canada, Remote Sensing of Environment, 141, 40-51, doi:10.1016/j.rse.2013.10.016, 2014.

Streletskiy, D. A., Shiklomanov, N. I., Little, J. D., Nelson, F. E., Brown, J., Nyland, K. E., and Klene, A. E.: Thaw Subsidence in Undisturbed Tundra Landscapes, Barrow, Alaska, 1962-2015, Permafrost and Periglac. Process., 58, 406, doi:10.1002/ppp.1918, 2016.

Wainwright, H. M., Dafflon, B., Smith, L. J., Hahn, M. S., Curtis, J. B., Wu, Y., Ulrich, C., Peterson, J. E., Torn, M. S., and Hubbard, S. S.: Identifying multiscale zonation and assessing the relative importance of polygon geomorphology on carbon fluxes in an Arctic tundra ecosystem, J. Geophys. Res. Biogeosci., 120, 788-808, doi:10.1002/2014JG002799, 2015. 
Earth Surf. Dynam. Discuss., https://doi.org/10.5194/esurf-2017-49

Manuscript under review for journal Earth Surf. Dynam.

Discussion started: 1 August 2017

(c) Author(s) 2017. CC BY 4.0 License.

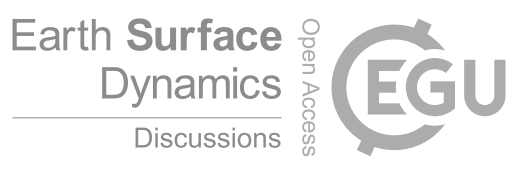

(c) (i)

Zimov, S. A., Schuur, E. A. G., and Chapin, F. S. 3.: Climate change. Permafrost and the global carbon budget, Science (New York, N.Y.), 312, 1612-1613, doi:10.1126/science.1128908, 2006. 
Earth Surf. Dynam. Discuss., https://doi.org/10.5194/esurf-2017-49

Manuscript under review for journal Earth Surf. Dynam.

Discussion started: 1 August 2017

(c) Author(s) 2017. CC BY 4.0 License.
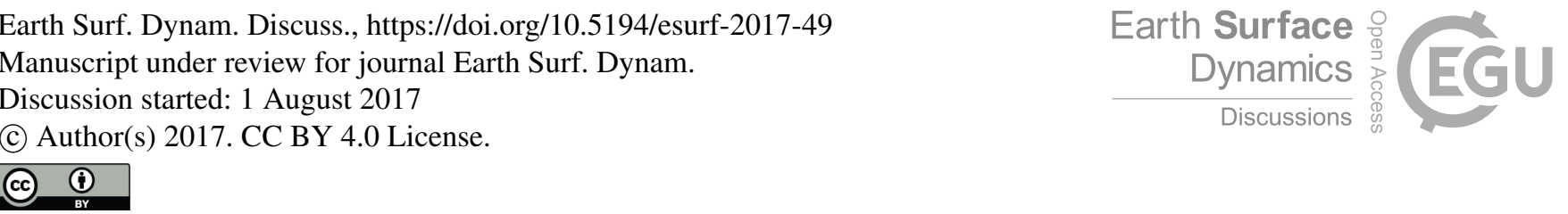

Figures

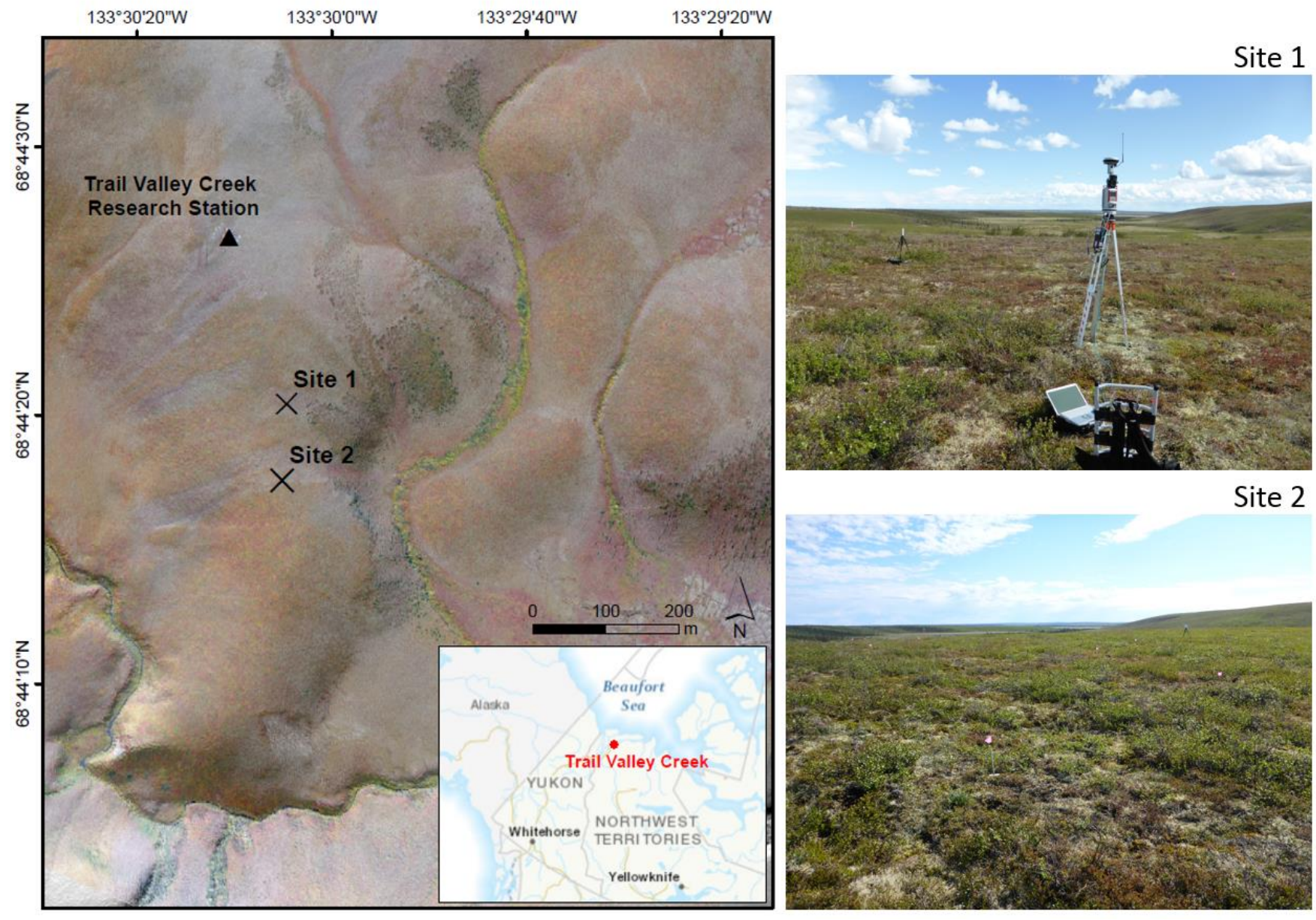

Figure 1: Map showing the location of the study sites (Trail Valley Creek, Northwest Territories, Canada). Data source: Canada Base Map (Natural Resources Canada), orthophoto captured in August 2015 (P. Marsh). On the right side, photos of study site 1 5 and site 2 are presented (photos were taken on June $8^{\text {th }}, 2015$ ). 
Earth Surf. Dynam. Discuss., https://doi.org/10.5194/esurf-2017-49

Manuscript under review for journal Earth Surf. Dynam.

Discussion started: 1 August 2017

(c) Author(s) 2017. CC BY 4.0 License.

(c) (1)
Earth Surface

Dynamics

Discussions

\section{TERRESTRIAL LASER SCANNING}

\section{Multi-temporal data acquisition}

(1) Repeated from similar scan positions

(2) Repeated from different scan positions
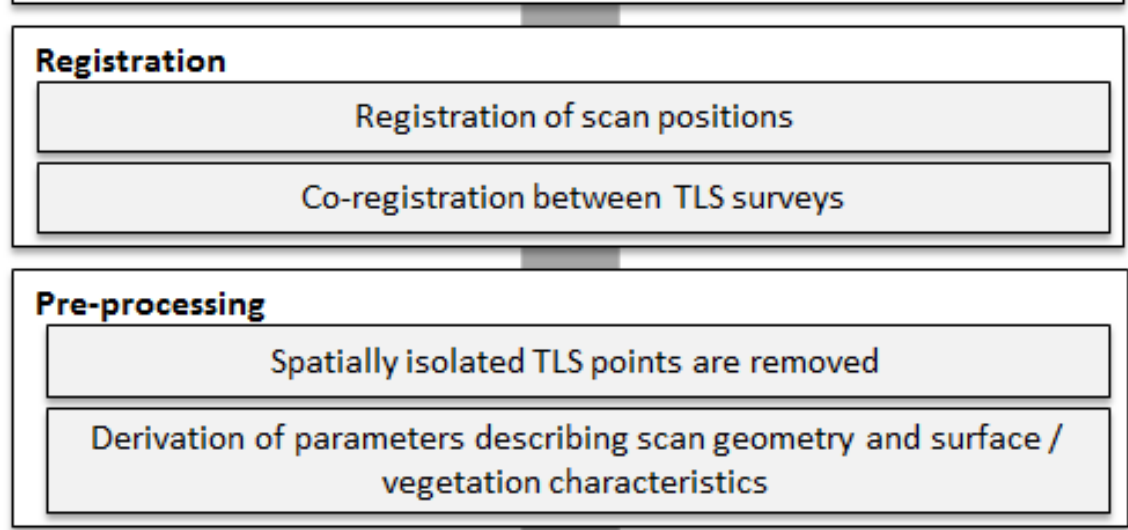

\section{Processing}

\begin{tabular}{|c|}
\hline DEM derivation \\
\hline Raster-based subsidence analysis \\
\hline Point-based subsidence analysis \\
1) M3C2 distance calculation based on all ground surface points \\
2) M3C2 distance calculation based on selected ground surface points \\
\hline
\end{tabular}

\section{REFERENCE DATASETS}

\section{Reference subsidence} rates

Multi-temporal GNSS ground surface measurements

Manual subsidence stations

\section{AnAlysis \& EVALUATION}

DEM accuracy assessment

Evaluation of subsidence rates obtained from TLS

Effect of scan geometry and surface / vegetation characteristics on TLS-based subsidence rates

Figure 2: Method of TLS-based deformation analysis for quantifying subsidence rates. 
Earth Surf. Dynam. Discuss., https://doi.org/10.5194/esurf-2017-49

Manuscript under review for journal Earth Surf. Dynam.

Discussion started: 1 August 2017

(c) Author(s) 2017. CC BY 4.0 License.

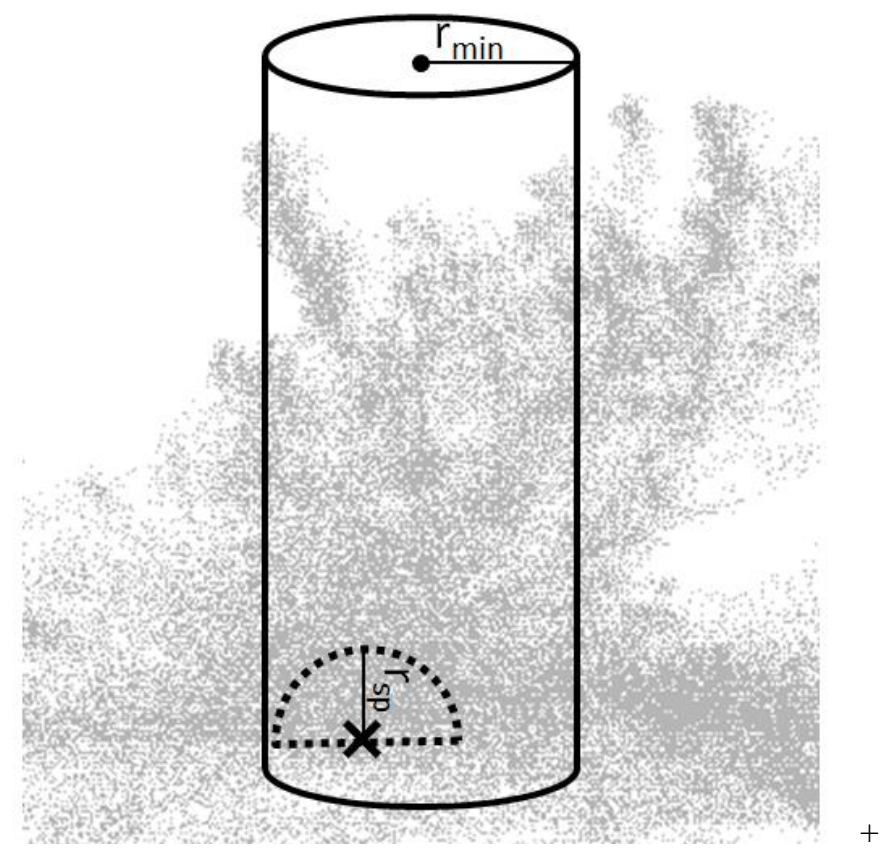

Figure 3: Infinite vertical search cylinder with search radius $\mathbf{r}_{\min }$ within the lowest TLS point is selected (grey points: TLS points representing a shrub). A point is regarded as being visible from more than one scan position if a TLS point from another scan position is found within a 3D sphere with radius $\mathbf{r}_{\mathrm{sp}}$.

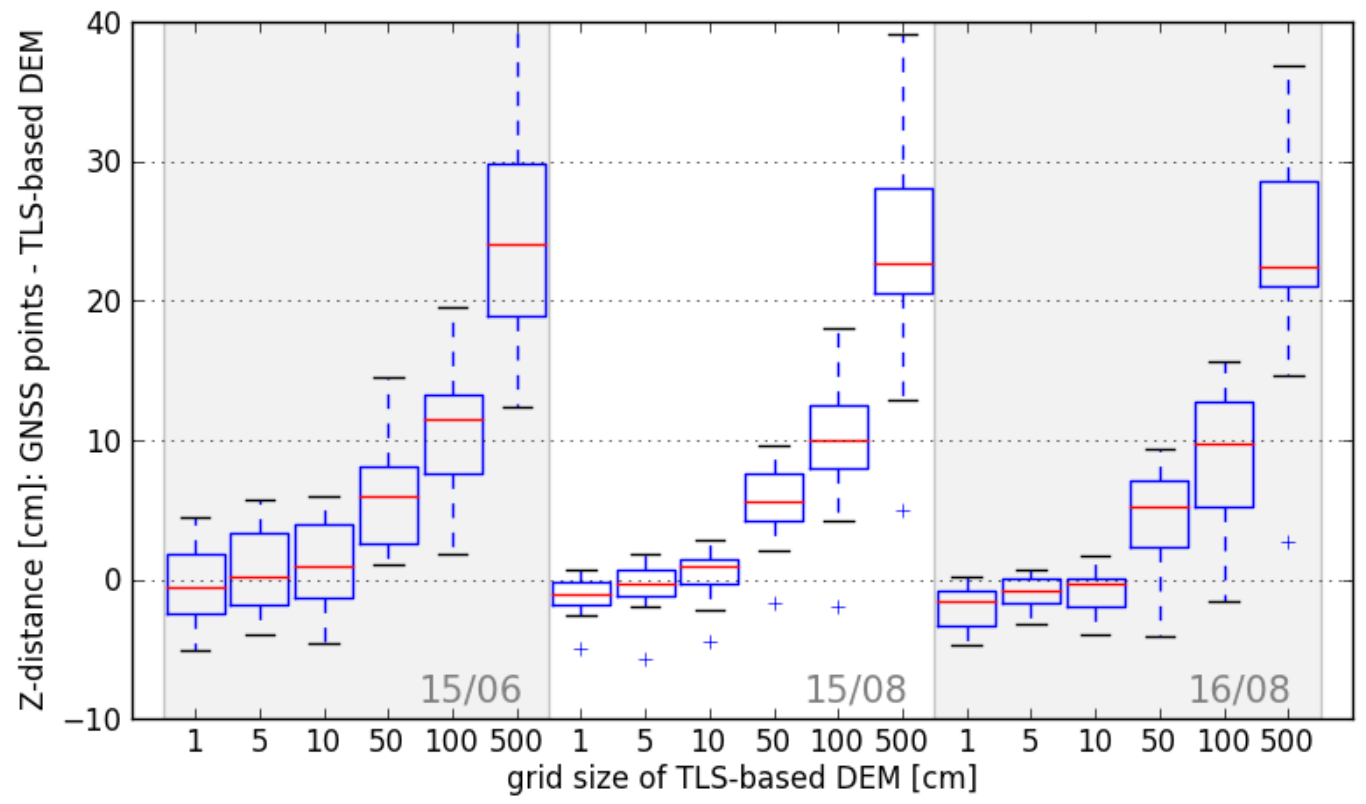

Figure 4: Boxplots showing the height differences between ground points captured via a GNSS rover in RTK mode and TLS-based DEMs. The results are presented for TLS-based DEMs (study site 1) with cell sizes between $1 \mathrm{~cm}$ and $500 \mathrm{~cm}$. 
Earth Surf. Dynam. Discuss., https://doi.org/10.5194/esurf-2017-49

Manuscript under review for journal Earth Surf. Dynam.

Discussion started: 1 August 2017

(c) Author(s) 2017. CC BY 4.0 License.

\section{Earth Surface \\ Dynamics \\ Discussions

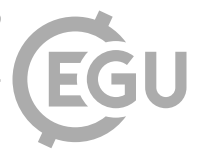

(c) (i)

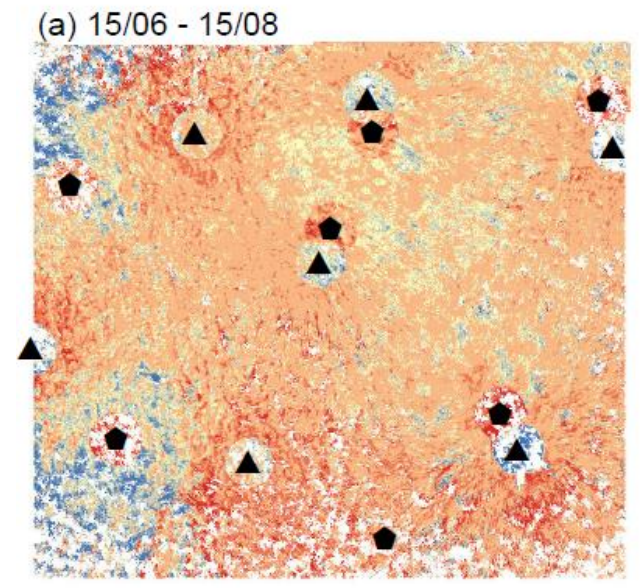

(b) mean incidence angles $(15 / 06,15 / 08)$

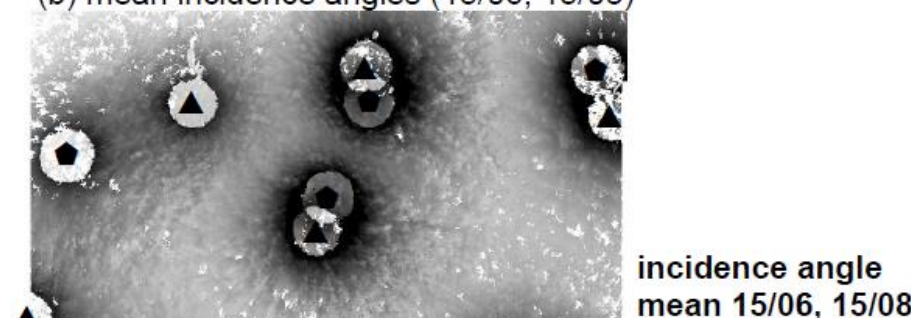

(c) $15 / 06-16 / 08$
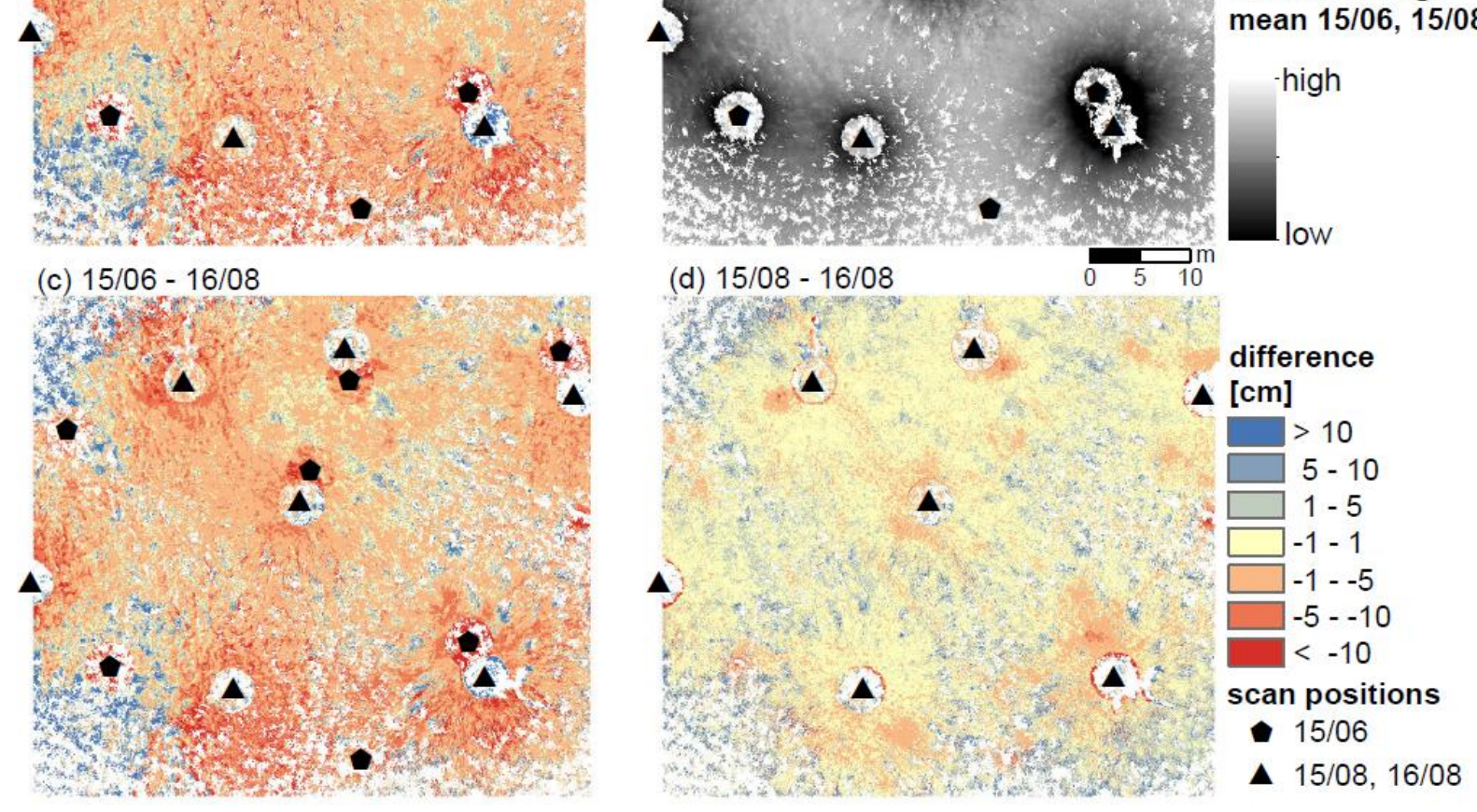

Figure 5: Vertical changes (in $\mathrm{cm}$ ) at study site 1 derived based on TLS data using DEM differencing. (a) shows the seasonal difference map between 2015/06-2015/08, (c) for 2015/06-2016/08 and (d) for annual difference between 2015/08-2016/08. In (b) the mean incidence angles of the laser beam is presented. 
Earth Surf. Dynam. Discuss., https://doi.org/10.5194/esurf-2017-49

Manuscript under review for journal Earth Surf. Dynam.

Discussion started: 1 August 2017

(c) Author(s) 2017. CC BY 4.0 License.

(c)

a) all $T L S_{\min }$ points

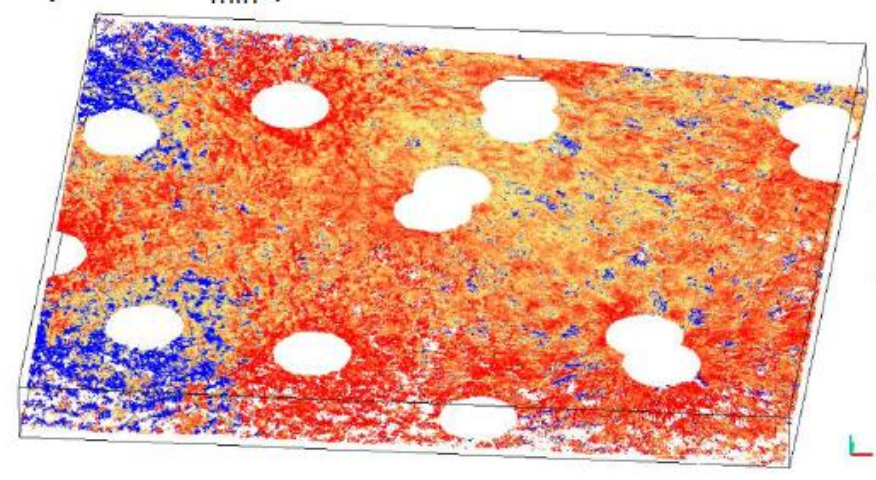

b) filter strategy (1)

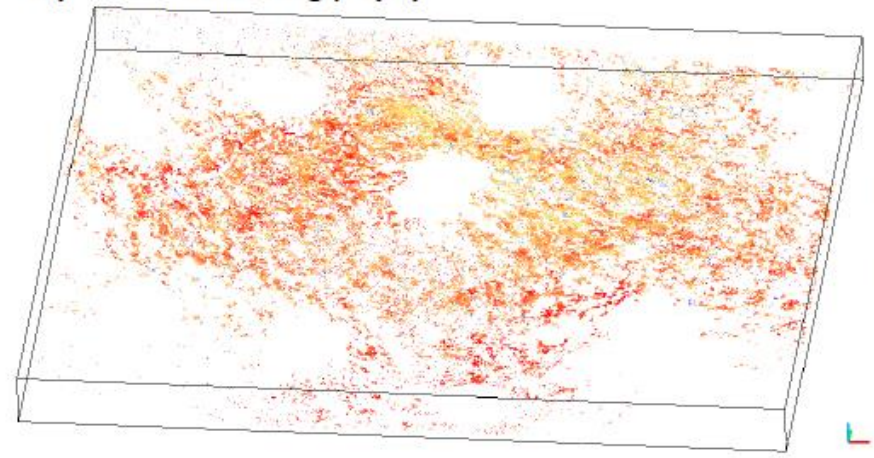

c) filter strategy (2)

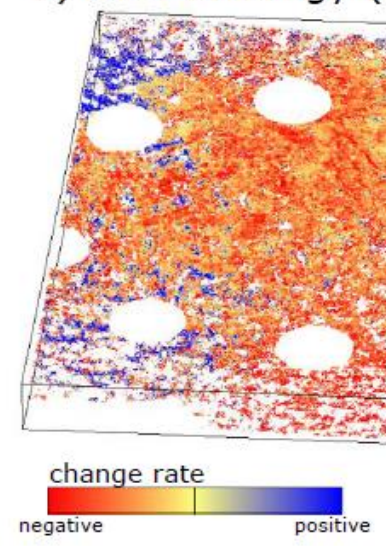

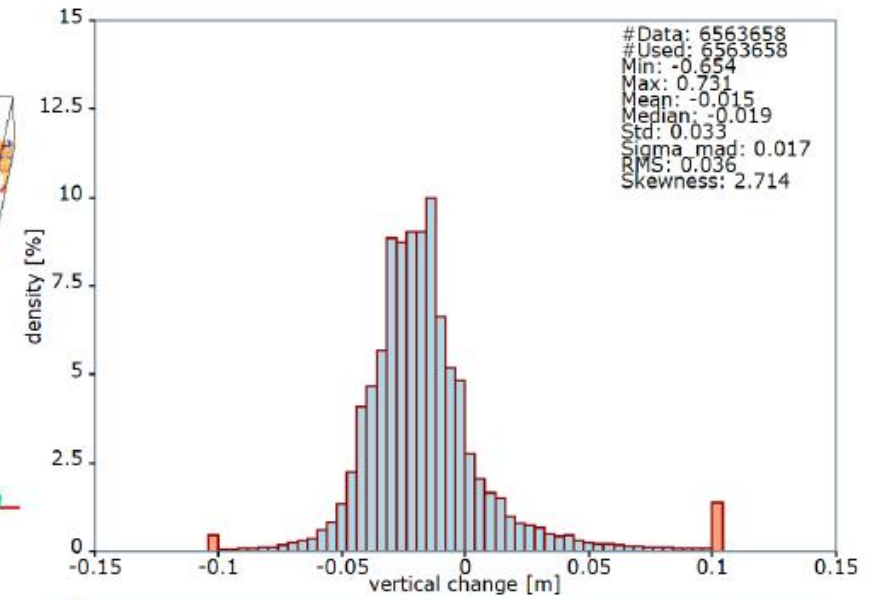
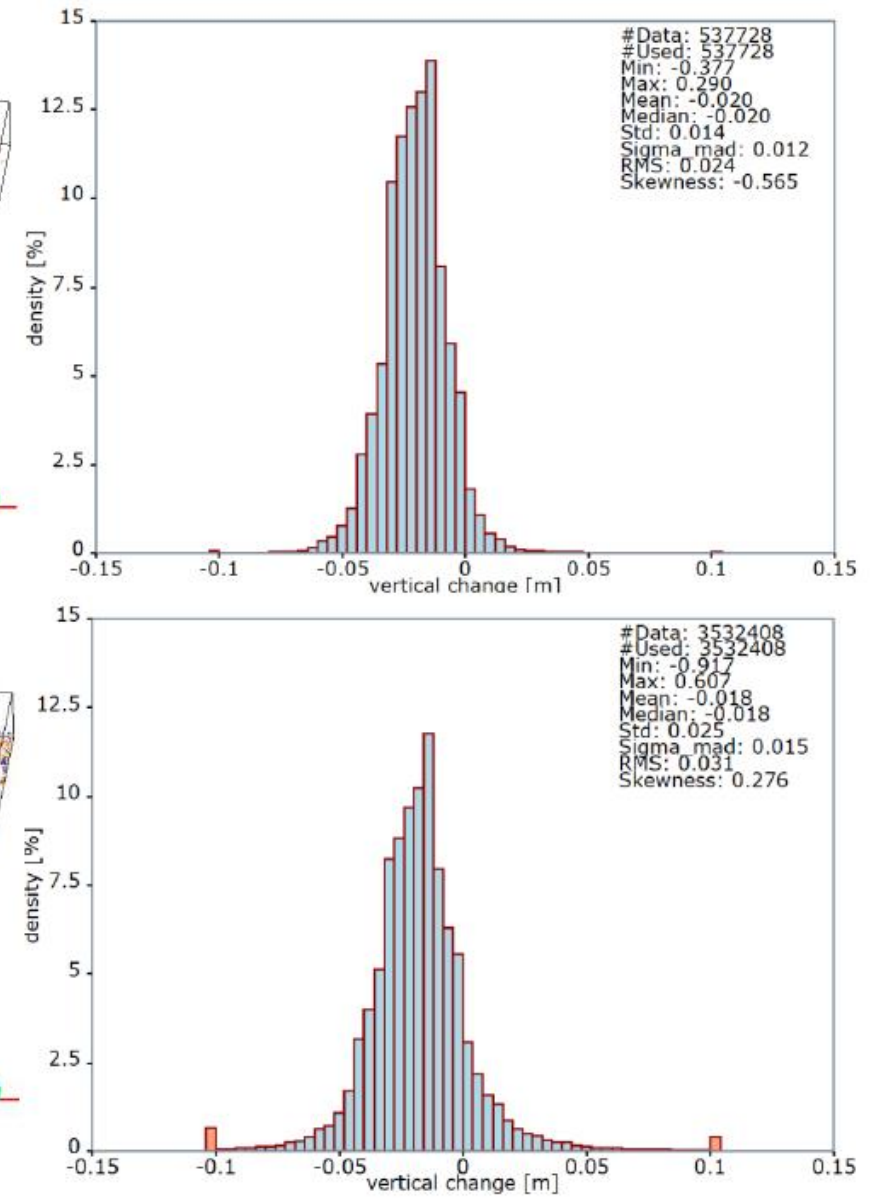

Figure 6: Vertical change rates using the $\mathrm{M3C2}$ distance calculation algorithm. Blue: positive change, red: negative change. Extent of site 1: approx. 50x50 m. The maps show study site 1, survey period 2015/06-2015/08. (a) presents the resulting change map using all local minimum points, (b) for points that are selected based on strategy 1 and (c) based on strategy 2. 
Earth Surf. Dynam. Discuss., https://doi.org/10.5194/esurf-2017-49

Manuscript under review for journal Earth Surf. Dynam.

Discussion started: 1 August 2017

(c) Author(s) 2017. CC BY 4.0 License.
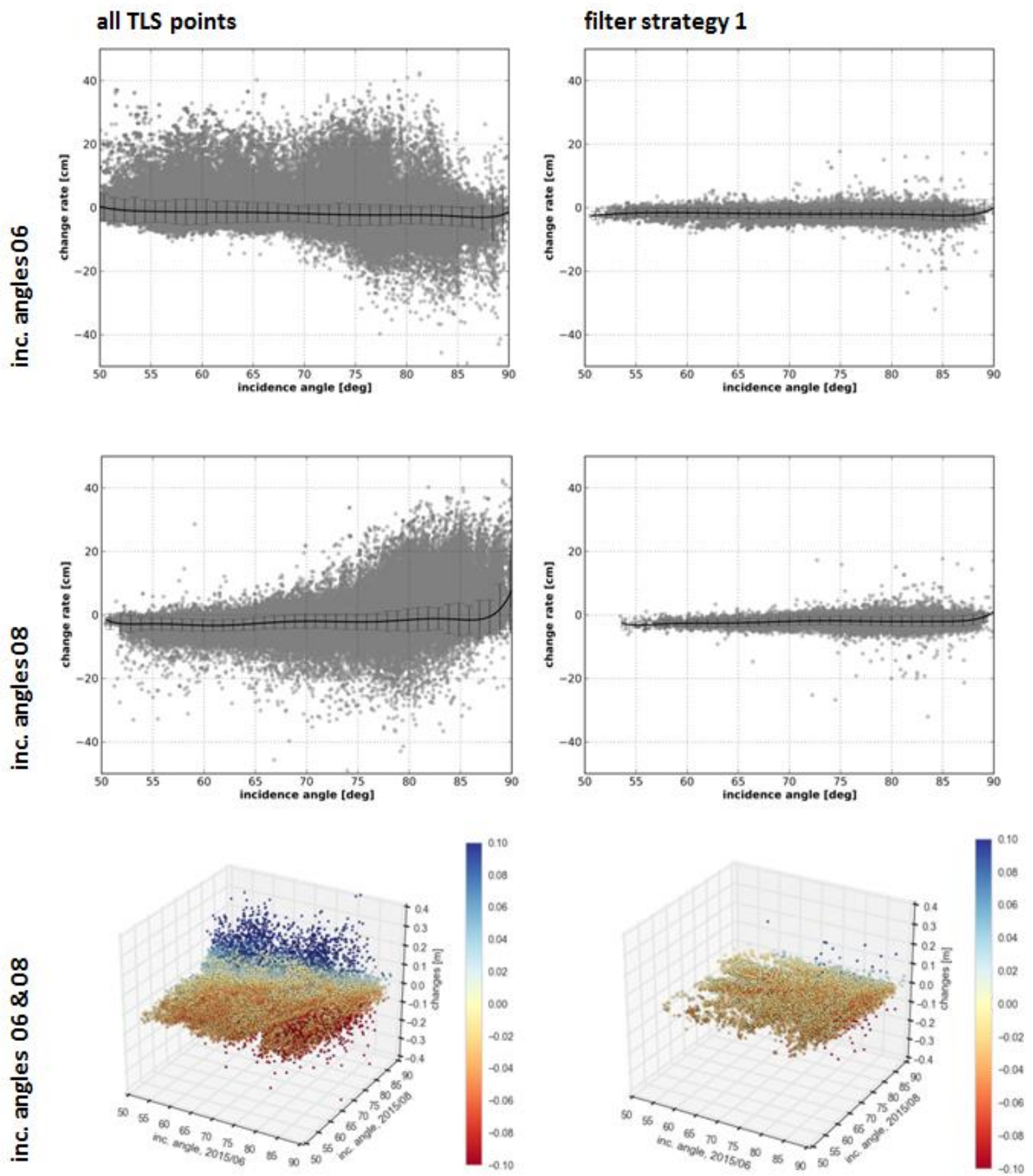

Figure 7: Plots showing change rates versus incidence angle for Site 1, 2015/06 - 2015/08; every $10^{\text {th }}$ TLS is displayed. For the dataset containing all TLS ${ }_{\min }$ points the calculated change rates depend on the incidence angle. With filter strategy 1 this effect is reduced. 
Earth Surf. Dynam. Discuss., https://doi.org/10.5194/esurf-2017-49

Manuscript under review for journal Earth Surf. Dynam.

Discussion started: 1 August 2017

(c) Author(s) 2017. CC BY 4.0 License.

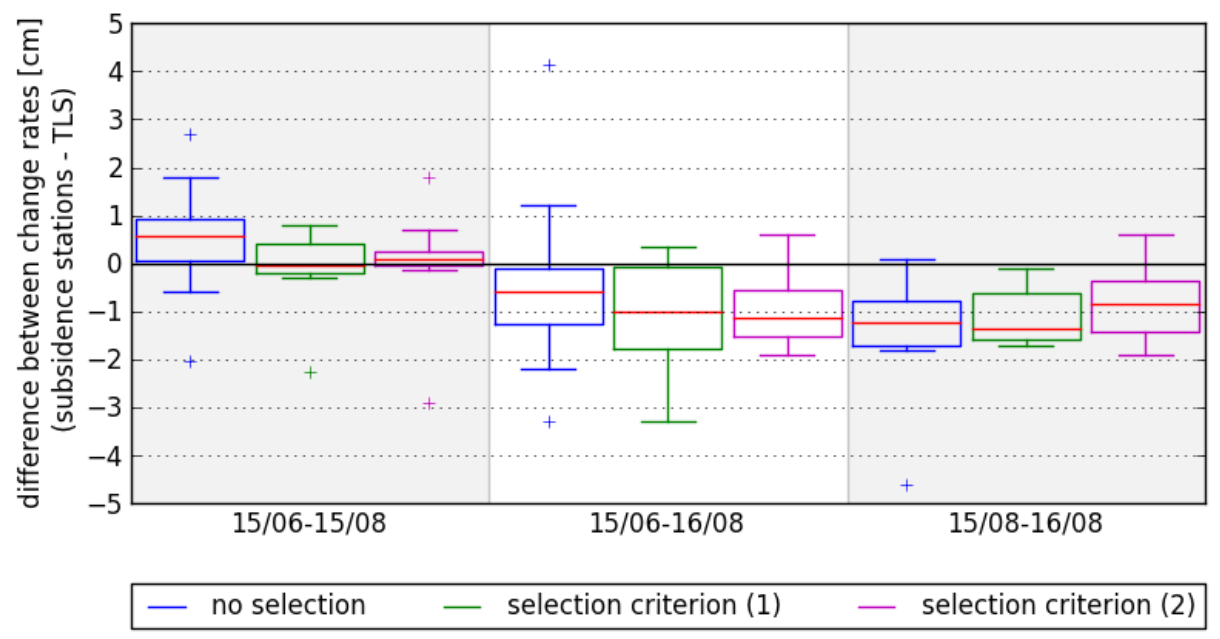

Figure 8: Boxplots visualizing the differences between change rates for site 1 derived based on TLS point clouds and gathered at 12 subsidence stations. Change rates are presented for all local minimum points (no selection) and for the point filter strategies. 
Earth Surf. Dynam. Discuss., https://doi.org/10.5194/esurf-2017-49

Manuscript under review for journal Earth Surf. Dynam.

Discussion started: 1 August 2017

(c) Author(s) 2017. CC BY 4.0 License.

\section{Earth Surface \\ Dynamics \\ Discussions

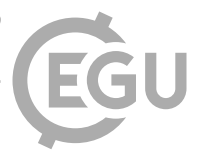

(c)

(a) point selection - filter strategy 1

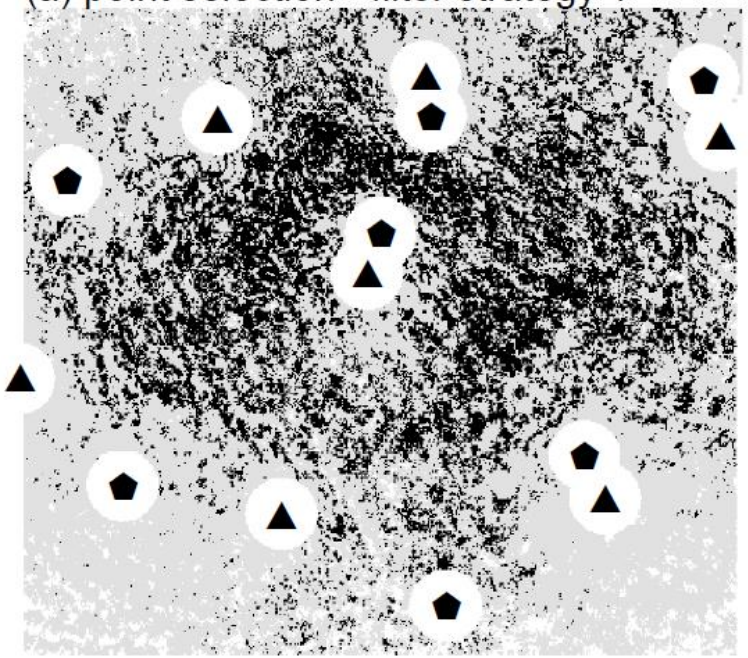

(c) microtopography - local minima

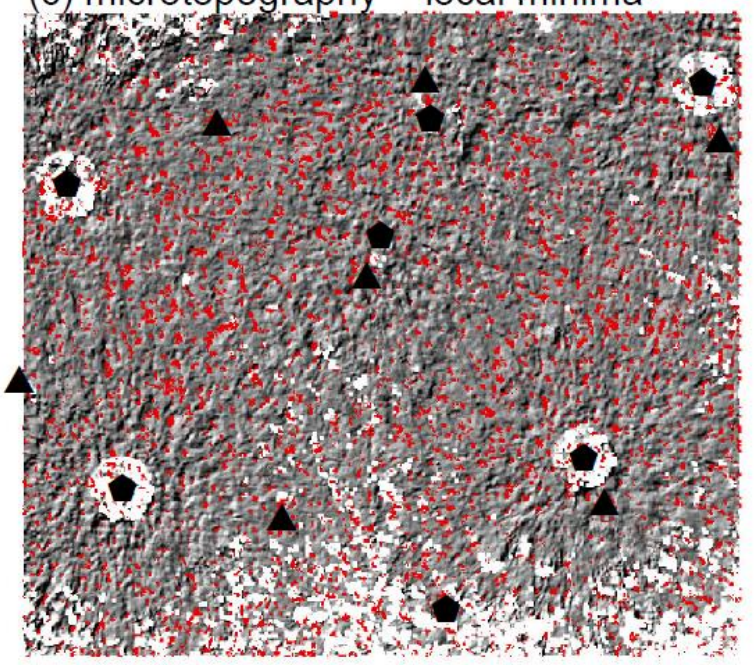

(b) vegetation height

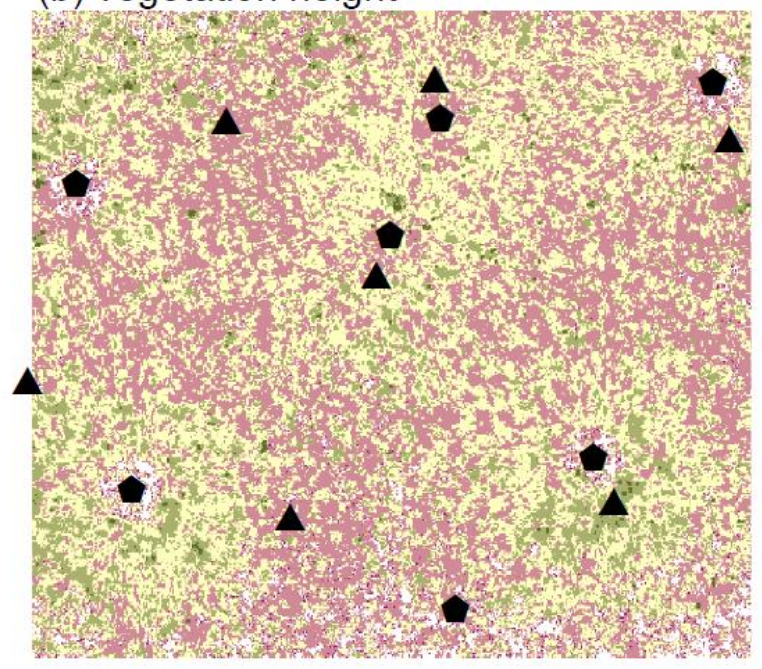

vegetation height

[m]

$0-0.1$

scan positions

- 15/06

A $15 / 08,16 / 08$
$0.1-0.25$

$0.25-0.5$

$0.5-1$

Figure 9: Maps showing vegetation characteristic of study site 1 (a) areas within site 1 selected by strategy 1 colored in black, (b) vegetation heights derived from TLS as range of z-values per pixel, and (c) local depressions colored in red. 
Earth Surf. Dynam. Discuss., https://doi.org/10.5194/esurf-2017-49

Tables

Table 1: RMSE and mean deviation of 3D- and z-distances (in $\mathrm{cm}$ ) at five control points that are distributed over site 1 and site 2 , respectively. Values are given before and after co-registration, which is performed for each survey period.

\begin{tabular}{lllll}
\hline & \multicolumn{2}{l}{ RMSE / Mean (3D-distances) } & \multicolumn{2}{l}{ RMSE / Mean (z-distances) } \\
\cline { 2 - 5 } & $\begin{array}{l}\text { before co- } \\
\text { registration }\end{array}$ & $\begin{array}{l}\text { after co- } \\
\text { registration }\end{array}$ & $\begin{array}{l}\text { before co- } \\
\text { registration }\end{array}$ & $\begin{array}{l}\text { after co- } \\
\text { registration }\end{array}$ \\
\hline $\begin{array}{l}\text { Site 1, } \\
\mathbf{2 0 1 5 / 0 6 - 2 0 1 5 / 0 8}\end{array}$ & $3.5 \mathrm{~cm} / 3.4 \mathrm{~cm}$ & $1.2 \mathrm{~cm} / 1.2 \mathrm{~cm}$ & $1.9 \mathrm{~cm} / 1.7 \mathrm{~cm}$ & $0.2 \mathrm{~cm} / 0.2 \mathrm{~cm}$ \\
\hline $\begin{array}{l}\text { Site 1, } \\
\mathbf{2 0 1 5 / 0 6 - 2 0 1 6 / 0 8}\end{array}$ & $5.2 \mathrm{~cm} / 5.0 \mathrm{~cm}$ & $1.8 \mathrm{~cm} / 1.5 \mathrm{~cm}$ & $4.0 \mathrm{~cm} / 3.9 \mathrm{~cm}$ & $0.2 \mathrm{~cm} / 0.2 \mathrm{~cm}$ \\
\hline $\begin{array}{l}\text { Site 1, } \\
\mathbf{2 0 1 5 / 0 8 - 2 0 1 6 / 0 8}\end{array}$ & $2.1 \mathrm{~cm} / 2.0 \mathrm{~cm}$ & $1.4 \mathrm{~cm} / 1.3 \mathrm{~cm}$ & $1.7 \mathrm{~cm} / 1.5 \mathrm{~cm}$ & $0.3 \mathrm{~cm} / 0.3 \mathrm{~cm}$ \\
\hline $\begin{array}{l}\text { Site 2, } \\
\mathbf{2 0 1 5 / 0 6 - 2 0 1 5 / 0 8}\end{array}$ & $4.8 \mathrm{~cm} / 4.8 \mathrm{~cm}$ & $0.5 \mathrm{~cm} / 0.5 \mathrm{~cm}$ & $0.5 \mathrm{~cm} / 0.4 \mathrm{~cm}$ & $0.1 \mathrm{~cm} / 0.1 \mathrm{~cm}$ \\
\hline $\begin{array}{l}\text { Site 2, } \\
\mathbf{2 0 1 5 / 0 6 - 2 0 1 6 / 0 8}\end{array}$ & $3.8 \mathrm{~cm} / 3.7 \mathrm{~cm}$ & $0.7 \mathrm{~cm} / 0.6 \mathrm{~cm}$ & $0.4 \mathrm{~cm} / 0.3 \mathrm{~cm}$ & $0.3 \mathrm{~cm} / 0.2 \mathrm{~cm}$ \\
\hline $\begin{array}{l}\text { Site 2, } \\
\mathbf{2 0 1 5 / 0 8 - 2 0 1 6 / 0 8}\end{array}$ & $1.5 \mathrm{~cm} / 1.4 \mathrm{~cm}$ & $0.7 \mathrm{~cm} / 0.7 \mathrm{~cm}$ & $0.3 \mathrm{~cm} / 0.3 \mathrm{~cm}$ & $0.2 \mathrm{~cm} / 0.2 \mathrm{~cm}$ \\
\hline
\end{tabular}

Table 2: Vertical change rates derived from TLS using M3C2 distance calculation and point selection.

\begin{tabular}{|c|c|c|c|c|c|c|c|}
\hline $\begin{array}{l}\text { point } \\
\text { count }\end{array}$ & $\begin{array}{l}\text { mean } \\
{[\mathrm{cm}]}\end{array}$ & $\begin{array}{l}\text { median } \\
{[\mathrm{cm}]}\end{array}$ & $\begin{array}{l}\text { range } \\
{[\mathrm{cm}]}\end{array}$ & $\begin{array}{l}\text { std. } \\
{[\mathrm{cm}]}\end{array}$ & $\begin{array}{l}\text { RMS } \\
{[\mathbf{c m}]}\end{array}$ & $\begin{array}{l}5 \% \\
\text { percentile } \\
{[\mathrm{cm}]}\end{array}$ & $\begin{array}{l}95 \% \\
\text { percentile } \\
{[\mathrm{cm}]}\end{array}$ \\
\hline
\end{tabular}

\begin{tabular}{|c|c|c|c|c|c|c|c|c|c|}
\hline Site 1 & & & & & & & & & 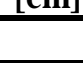 \\
\hline \multirow{3}{*}{$\begin{array}{l}\text { 2015/06- } \\
\mathbf{2 0 1 5} / 08\end{array}$} & no selection & $6,563,658$ & -1.5 & -1.9 & 138.5 & 3.3 & 3.6 & -6.5 & 8.0 \\
\hline & selection (1) & 537,728 & -2.0 & -2.0 & 66.7 & 1.4 & 2.4 & -4.1 & 0.1 \\
\hline & selection (2) & $3,532,408$ & -1.8 & -1.8 & 152.4 & 2.5 & 3.1 & -7.3 & 2.9 \\
\hline \multirow{3}{*}{$\begin{array}{l}2015 / 06- \\
2016 / 08\end{array}$} & no selection & $6,312,865$ & -1.6 & -2.2 & 135.5 & 4.0 & 4.4 & -7.0 & 11.1 \\
\hline & selection (1) & 555,909 & -2.2 & -2.4 & 85.5 & 2.0 & 3.0 & -4.9 & 1.2 \\
\hline & selection (2) & $3,381,766$ & -2.0 & -2.3 & 160.1 & 3.1 & 3.7 & -6.5 & 4.0 \\
\hline \multirow{3}{*}{$\begin{array}{l}\text { 2015/08- } \\
2016 / 08\end{array}$} & no selection & $7,507,527$ & -0.3 & -0.4 & 105.7 & 1.8 & $\overline{1.8}$ & -2.3 & 3.0 \\
\hline & selection (1) & 511,819 & -0.3 & -0.4 & 104.9 & 1.4 & 1.5 & -2.1 & 1.7 \\
\hline & selection (2) & $3,517,524$ & -0.3 & -0.4 & 115.6 & 2.1 & 2.1 & -2.8 & 3.1 \\
\hline \multicolumn{10}{|l|}{ Site 2} \\
\hline \multirow{3}{*}{$\begin{array}{l}\text { 2015/06- } \\
2015 / 08\end{array}$} & no selection & $6,799,805$ & -0.9 & -1.5 & 127.7 & 3.7 & 3.8 & -4.4 & 9.4 \\
\hline & selection (1) & 527,908 & -1.5 & -1.8 & 108.2 & 2.8 & 3.2 & -4.4 & 3.5 \\
\hline & selection (2) & $3,223,854$ & -1.1 & -1.5 & 128.2 & 3.3 & 3.5 & -4.5 & 5.6 \\
\hline \multirow{3}{*}{$\begin{array}{l}\text { 2015/06- } \\
2016 / 08\end{array}$} & no selection & $6,753,521$ & -1.0 & -1.8 & 126.0 & 4.2 & 4.3 & -4.8 & 10.4 \\
\hline & selection (1) & 499,749 & -1.7 & -2.3 & 113.2 & 3.3 & 3.7 & -5.3 & 4.7 \\
\hline & selection (2) & $3,163,541$ & -1.2 & -1.8 & 140.3 & 3.8 & 4.0 & -5.2 & 6.7 \\
\hline \multirow{3}{*}{$\begin{array}{l}2015 / 08- \\
2016 / 08\end{array}$} & no selection & $7,120,644$ & -0.3 & -0.4 & 134.9 & 1.8 & $\overline{1.9}$ & -2.3 & 3.0 \\
\hline & selection (1) & 648,081 & -0.3 & -0.5 & 81.6 & 2.1 & 2.1 & -2.1 & 1.7 \\
\hline & selection (2) & $3,617,038$ & -0.2 & -0.4 & 127.0 & 2.3 & 2.3 & -2.8 & 3.1 \\
\hline
\end{tabular}


Earth Surf. Dynam. Discuss., https://doi.org/10.5194/esurf-2017-49

Manuscript under review for journal Earth Surf. Dynam.

Discussion started: 1 August 2017

(c) Author(s) 2017. CC BY 4.0 License.

(c) (1)

\section{Appendix}

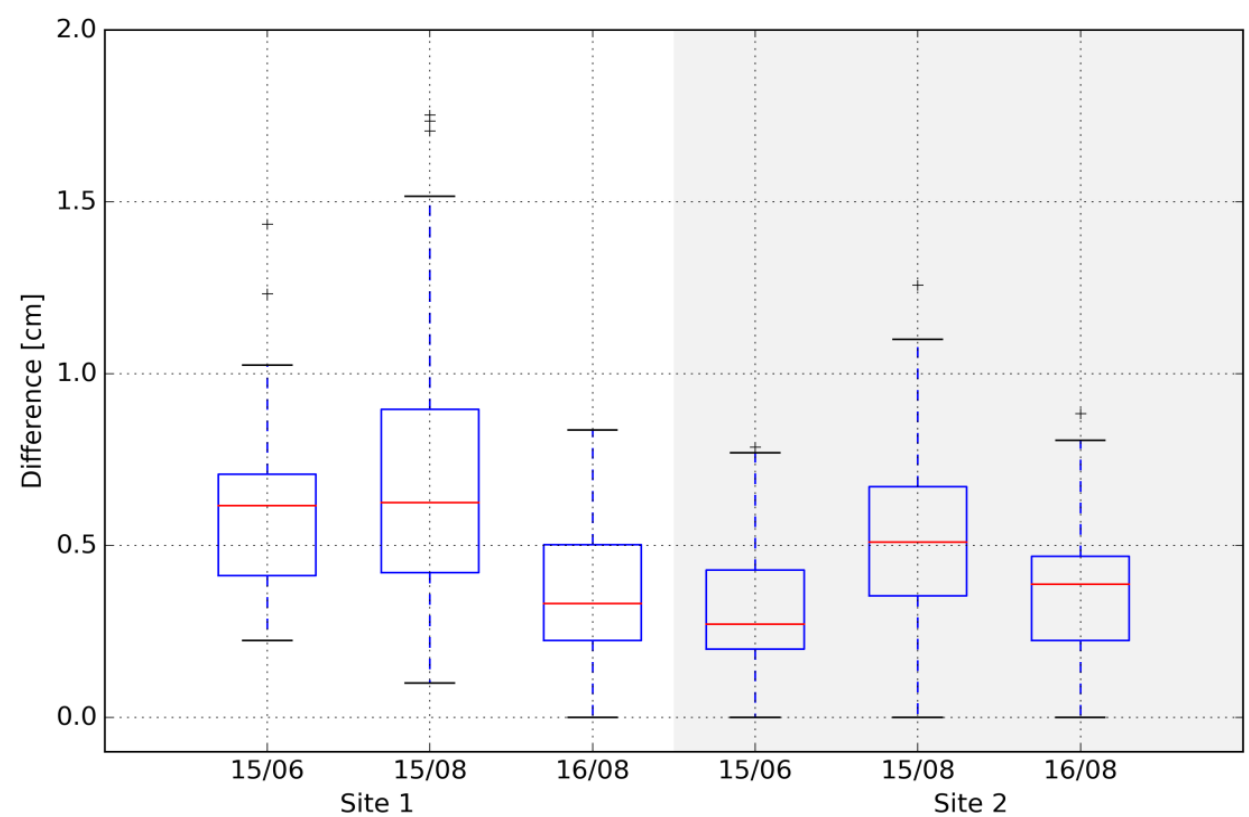

Appendix 1: 3D distances (in $\mathrm{cm}$ ) between the single scan positions at four reflector tiepoints as measure for the registration error. Boxplots are presented for site 1 and for site 2 and each survey date (2015/06, 2015/08, 2016/08).

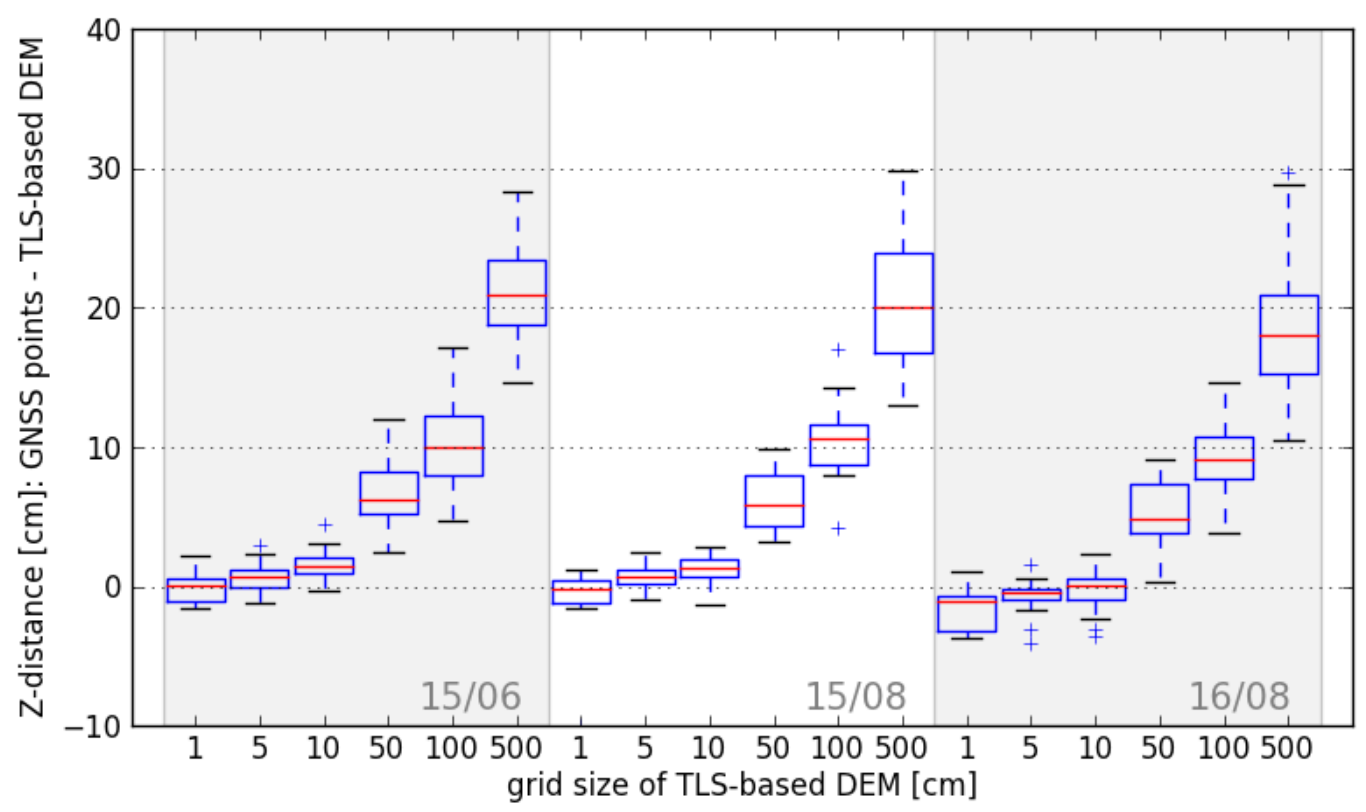

5 Appendix 2: Boxplots showing z-distances between ground heights captured via a GNSS rover in RTK mode and TLS-based DEMs. The results are presented for TLS-based DEMs (study site 2) with cell sizes between $1 \mathrm{~cm}$ and $500 \mathrm{~cm}$. 
Earth Surf. Dynam. Discuss., https://doi.org/10.5194/esurf-2017-49

\begin{tabular}{|c|c|c|c|c|c|c|c|c|}
\hline & $\begin{array}{ll}\text { DEM } & \text { res. } \\
{[\mathrm{cm}]} & \\
\end{array}$ & $\begin{array}{l}\text { RMSE } \\
{[\mathrm{cm}]}\end{array}$ & $\begin{array}{l}\text { mean } \\
\text { error }[\mathrm{cm}]\end{array}$ & std. $[\mathrm{cm}]$ & $\begin{array}{l}\text { median } \\
{[\mathrm{cm}]}\end{array}$ & NMAD & $\begin{array}{l}68.3 \% \\
\text { quantile }\end{array}$ & $\begin{array}{l}95 \% \\
\text { quantile }\end{array}$ \\
\hline \multirow{3}{*}{$\begin{array}{lr}\text { Site } 1 \\
2015 / 06\end{array}$} & 1 & 3.04 & -0.34 & 3.02 & -0.54 & 3.07 & 3.38 & 5.08 \\
\hline & 5 & 3.09 & 0.55 & 3.04 & 0.24 & 4.09 & 3.69 & 5.68 \\
\hline & 10 & 3.32 & 0.96 & 3.18 & 0.93 & 4.35 & 3.93 & 5.83 \\
\hline \multirow{3}{*}{$\begin{array}{lr}\text { Site } 1 \\
2015 / 08\end{array}$} & 1 & 1.75 & -1.10 & 1.36 & -1.05 & 1.26 & 1.70 & 3.43 \\
\hline & 5 & 4.30 & -1.19 & 4.13 & -0.30 & 1.56 & 1.41 & 16.13 \\
\hline & 10 & 1.64 & 0.45 & 1.58 & 0.90 & 1.56 & 1.52 & 4.00 \\
\hline \multirow{3}{*}{$\begin{array}{lr}\text { Site } 1 \\
2016 / 08\end{array}$} & 1 & 4.37 & -2.68 & 3.46 & -1.50 & 2.22 & 3.20 & 14.61 \\
\hline & 5 & 1.48 & -0.95 & 1.14 & -0.77 & 1.14 & 1.23 & 3.15 \\
\hline & 10 & 4.14 & -1.36 & 3.91 & -0.31 & 1.42 & 1.74 & 15.61 \\
\hline \multirow{3}{*}{$\begin{array}{lr}\text { Site } 2 \\
2015 / 06\end{array}$} & 1 & 0.99 & -0.02 & 0.99 & 0.05 & 0.97 & 1.03 & 2.22 \\
\hline & 5 & 1.22 & 0.60 & 1.06 & 0.76 & 0.77 & 1.15 & 2.90 \\
\hline & 10 & 1.92 & 1.62 & 1.04 & 1.50 & 0.88 & 1.95 & 4.53 \\
\hline \multirow{3}{*}{$\begin{array}{lr}\text { Site } \quad 2 \\
2015 / 08\end{array}$} & 1 & 11.90 & -4.62 & 10.96 & -0.15 & 1.06 & 1.16 & 39.39 \\
\hline & 5 & 1.08 & 0.65 & 0.86 & 0.70 & 0.74 & 1.03 & 2.44 \\
\hline & 10 & 1.60 & 1.24 & 1.00 & 1.30 & 1.04 & 1.87 & 2.80 \\
\hline \multirow{3}{*}{$\begin{array}{lr}\text { Site } 2 \\
2016 / 08\end{array}$} & 1 & 2.14 & -1.50 & 1.52 & -1.09 & 1.66 & 2.81 & 3.64 \\
\hline & 5 & 3.67 & -1.41 & 3.39 & -0.43 & 0.81 & 1.10 & 12.98 \\
\hline & 10 & 1.51 & -0.19 & 1.49 & 0.11 & 1.05 & 1.43 & 3.62 \\
\hline
\end{tabular}

Appendix 3: Quality measures derived for the TLS-based DEMs using GNSS measurements as reference dataset.

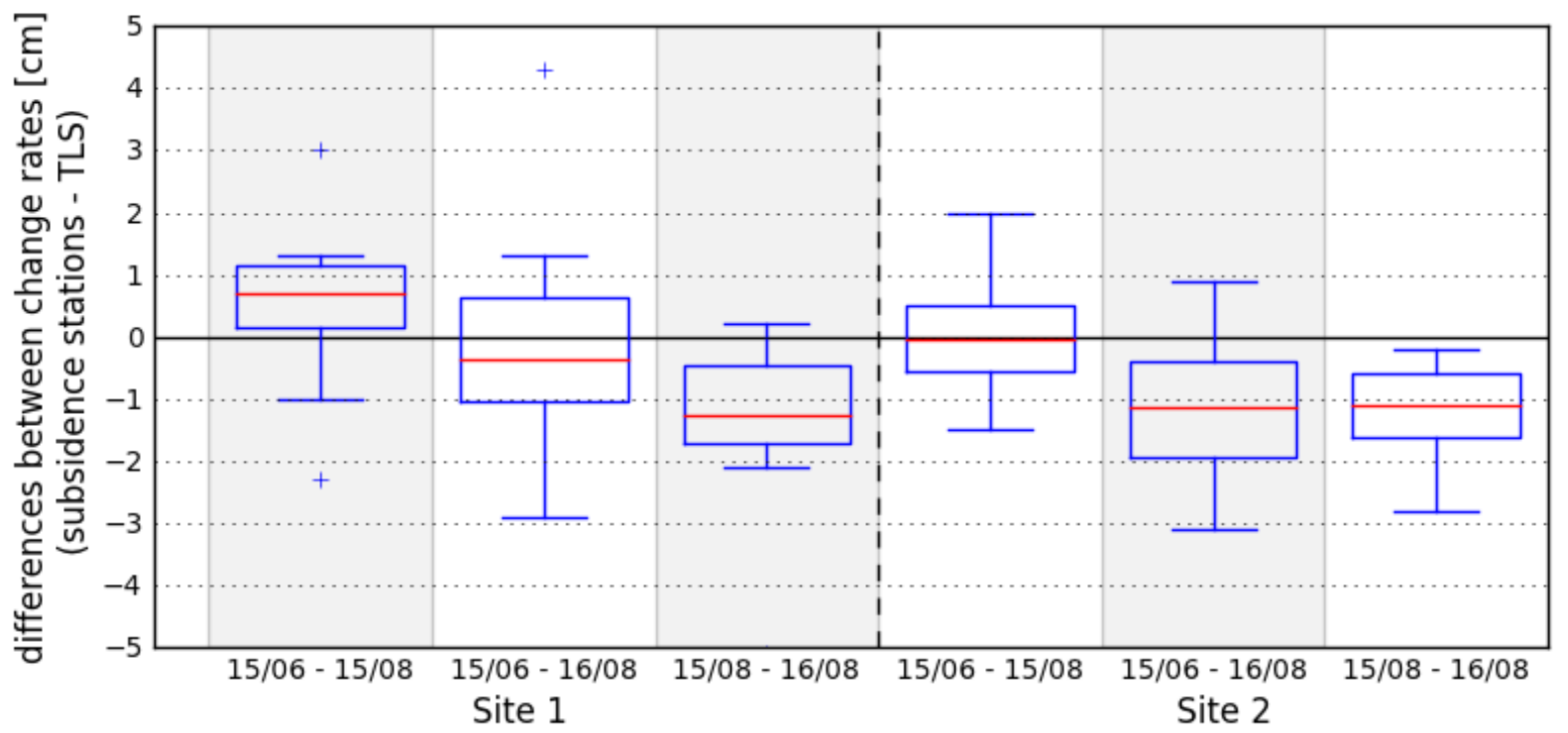

Appendix 4: Differences between change rates derived from manual subsidence station and TLS-based difference DEMs. 
Earth Surf. Dynam. Discuss., https://doi.org/10.5194/esurf-2017-49

Manuscript under review for journal Earth Surf. Dynam.

Discussion started: 1 August 2017

(c) Author(s) 2017. CC BY 4.0 License.

\section{Earth Surface \\ Dynamics \\ Discussions

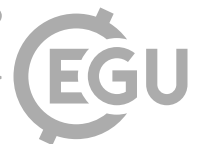

(c) (i)
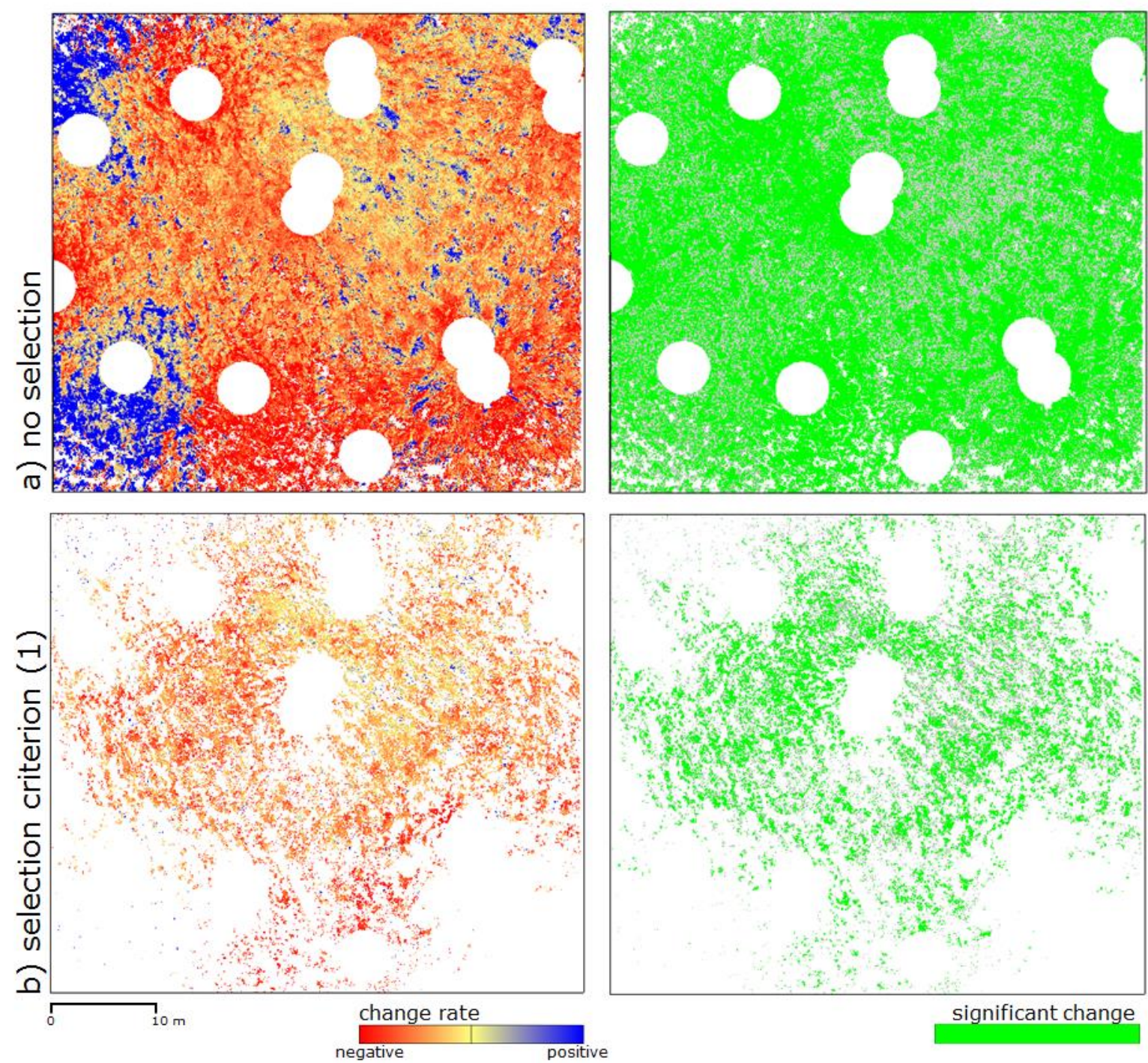

Appendix 5: Maps of topographic changes calculated with the M3C2 algorithm (a) without point selection and (b) after applying point filter strategy 1 . On the right side points with significant change rates are colored in green. Uncertainties are calculated based on (co-)registration error and local surface roughness using the $\mathrm{M3C} 2$ tool. 
Earth Surf. Dynam. Discuss., https://doi.org/10.5194/esurf-2017-49

Manuscript under review for journal Earth Surf. Dynam.

Discussion started: 1 August 2017

a) no selection

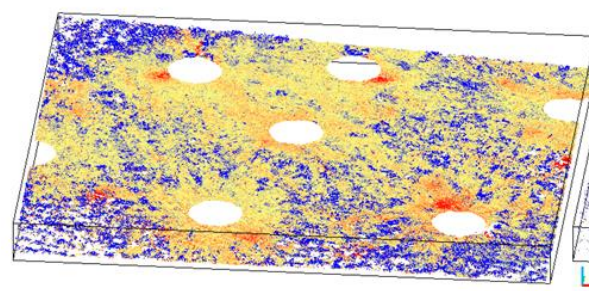

b) selection (1)

c) selection (2)

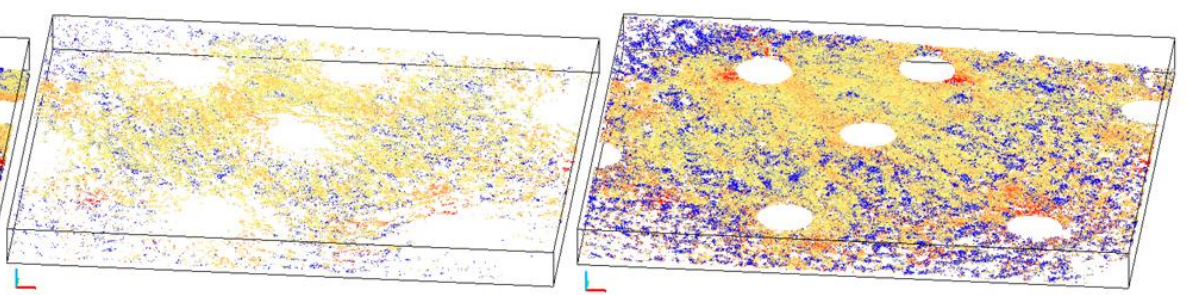

Appendix 6: Vertical change rates using the $\mathrm{M3C2}$ distance calculation algorithm. Blue: positive change, red: negative change. The maps show study site 1 , survey period 2015/08-2016/08. (a) presents the resulting change map using all local minimum points, (b) for points that are selected based on strategy 1 and (c) based on strategy 2.

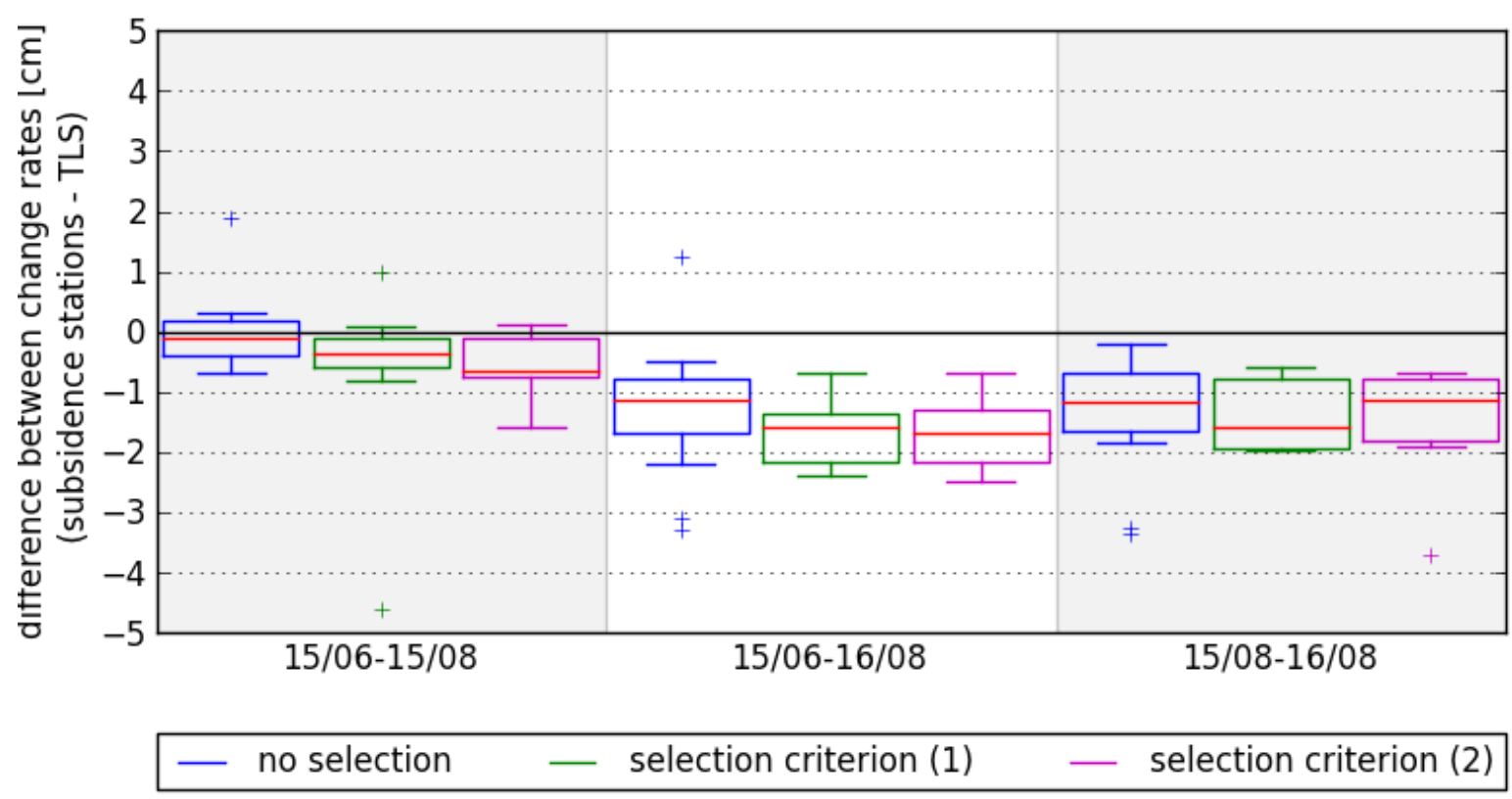

Appendix 7: Boxplots visualizing the differences between change rates for site 2 derived based on TLS point clouds and gathered at 12 subsidence stations. Change rates are presented for all local minimum points (no selection) and for the point filter strategies. 
Earth Surf. Dynam. Discuss., https://doi.org/10.5194/esurf-2017-49

Manuscript under review for journal Earth Surf. Dynam.

Discussion started: 1 August 2017

(c) Author(s) 2017. CC BY 4.0 License.

\section{Earth Surface \\ Dynamics \\ Discussions

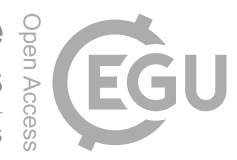

(c) (1)

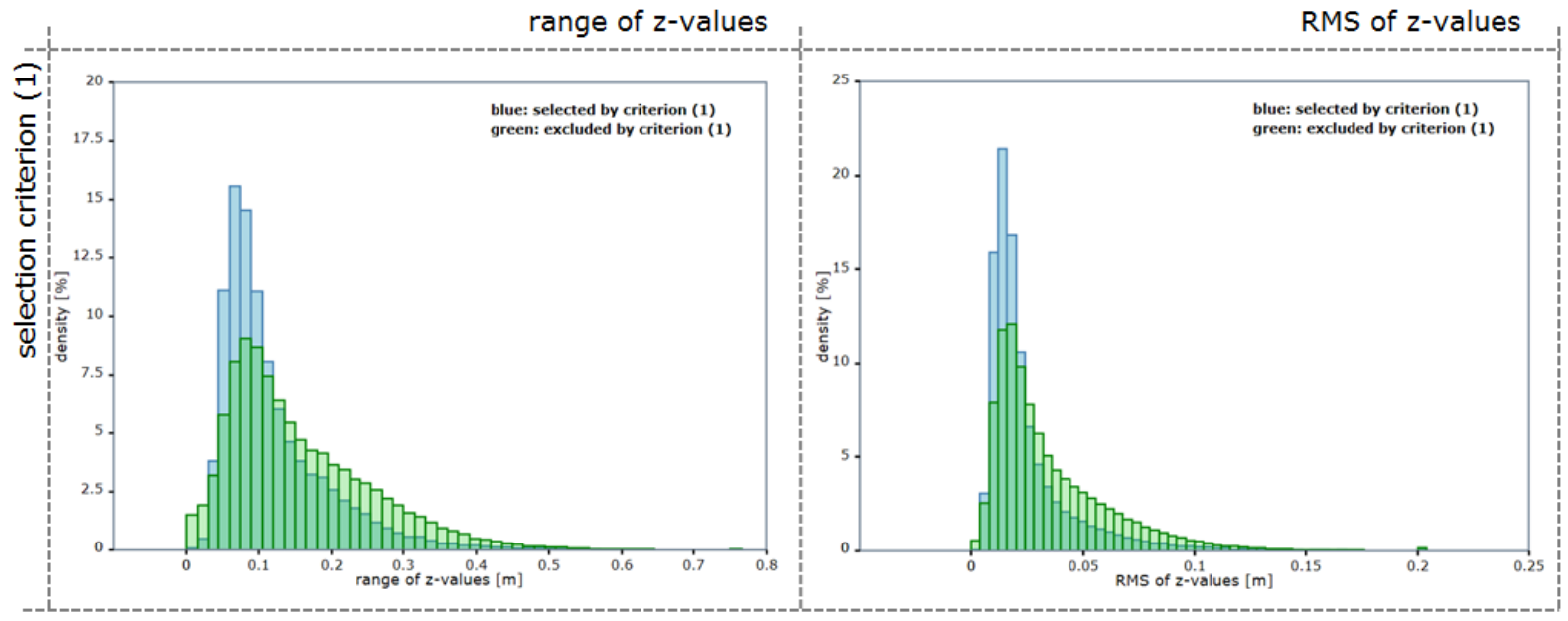

Appendix 8: Histograms showing the distribution of range of TLS z-values and RMS of z-values for the area selected for the deformation analysis by filter strategy 1 and the excluded parts. 